\title{
Predicting potentially toxic elements in tropical soils from iron oxides, magnetic susceptibility and diffuse reflectance spectra
}

\author{
Livia Arantes Camargo ${ }^{\mathrm{a}, *}$, José Marques Jr. ${ }^{\mathrm{a}}$, Vidal Barrón ${ }^{\mathrm{b}}$, Luís Reynaldo Ferracciú Alleoni ${ }^{\mathrm{c}}$, \\ Gener Tadeu Pereira ${ }^{a}$, Daniel De Bortoli Teixeira ${ }^{\mathrm{d}}$, Angélica Santos Rabelo de Souza Bahia ${ }^{\mathrm{a}}$ \\ a São Paulo State University (UNESP), Faculdade de Ciências Agrárias e Veterinárias, Research Group CSME - Soil Characterization for Specific Management, Campus de \\ Jaboticabal, Via de Acesso Prof. Paulo Donato Castellane, $s / n^{\circ}$, 14884-900 Jaboticabal, SP, Brazil \\ bepartamento de Agronomía, Universidad de Córdoba, Edificio C4, Campus de Rabanales, 14071 Córdoba, Spain \\ ${ }^{\mathrm{c}}$ Luiz de Queiroz College of Agriculture (ESALQ), University of Sao Paulo (USP), CP 09, 13418-900 Piracicaba, SP, Brazil \\ d Agrarian Sciences Center, University of Marília, Higyno Muzzy Filho Avenue, 1001, 17.525-902 Marília, SP, Brazil
}

\section{A R T I C L E I N F O}

\section{Keywords:}

Heavy metals

Spatial variability

Goethite

Hematite

Pedotransfer function

Chemometrics

\begin{abstract}
A B S T R A C T
Environmental impacts can be more accurately assessed with the aid of spatial characterization of potentially toxic elements (PTEs). In fact, developing cost-effective, environmentally friendly spatial characterization methods for PTEs can facilitate the expeditious, accurate, detailed diagnosis of soil in large areas. In this study, we used three geomorphic surfaces of Oxisols to assess the ability of chemical and X-ray diffraction analyses of iron oxides, diffuse reflectance spectroscopy (DRS) and magnetic susceptibility (MS) measurements to predict the contents in PTEs ( $\mathrm{Ba}, \mathrm{Co}, \mathrm{Cr}, \mathrm{Cu}, \mathrm{Mn}, \mathrm{Mo}, \mathrm{Ni}, \mathrm{Pb}$ and $\mathrm{Zn}$ ) and their spatial variability. Magnetic susceptibility and diffuse reflectance spectroscopy allowed well-calibrated prediction models for $\mathrm{Ba}, \mathrm{Co}, \mathrm{Cu}, \mathrm{Mn}$ and $\mathrm{Ni}$ to be developed, whereas DRS-calibrated methods afforded more accurate prediction of $\mathrm{Ba}$ and Mn contents, and magnetic susceptibility-calibrated methods of Co and Ni contents. The correlation between PTEs and free iron contents, and their spatial pattern, testifies to the goodness of the proposed methods for predicting the contents of potentially toxic elements in soils.
\end{abstract}

\section{Introduction}

Agriculture is a major source of potentially toxic elements (PTEs) in soil worldwide, but particularly in heavily cultivated areas (Alloway, 1995). Characterizing the spatial distribution of PTEs in farming areas is crucial to assessing the environmental impact of soil contamination (Cattle et al., 2002). Geostatistics at different scales is one commonly used tool for this purpose (Burak et al., 2010; Lin et al., 2014; Nanos and Martín, 2012). In fact, geostatistical maps are useful for identifying contaminated areas to assist decision-making. However, geostatistical analyses of large areas require using also large numbers of samples, which makes laboratory determinations of PTEs contents unfeasible for obvious economic and time-related reasons. A need for cost-effective, environmentally friendly methods for the spatial characterization of element contents therefore exists to facilitate the rapid, accurate diagnosis of large areas at a detailed level.

Prediction models can be highly useful for characterizing spatial variability in continuous variables such as soil attributes, which involves using large numbers of samples with conventional methods
(Lagacherie and McBratney, 2007). Because they co-precipitate with, and specifically adsorb, $\mathrm{Co}, \mathrm{Cr}, \mathrm{Cu}, \mathrm{Mn}, \mathrm{Mo}, \mathrm{Ni}, \mathrm{Zn}$ and As from solution (Alloway, 1995), iron, aluminium and manganese oxides play a central role in PTEs chemistry and behaviour. PTEs contents can thus be expected to change in parallel with iron oxides, and iron oxides to be effective PTEs predictors for highly weathered soils such as Oxisols the predominant soil order in tropical regions.

Magnetic susceptibility (MS) is an effective technique for predicting soil attributes influenced by iron oxides such as adsorbed phosphorus (Camargo et al., 2016), and also for assessing metal contamination of soil (Morton-Bermea et al., 2009).

Diffuse reflectance spectroscopy (DRS) provides a rapid, inexpensive, non-destructive prediction tool for the simultaneous characterization of various soil attributes (Camargo et al., 2015; Colombo et al., 2014; Guerrero et al., 2016; Viscarra-Rossel et al., 2010; Viscarra Rossel et al., 2016). Although low concentrations of PTEs preclude observation of their spectral features, PTEs contents can be predicted by examining the relationship between soil attributes such as iron oxides and spectral features (Stenberg et al., 2010; Wu et al., 2007). The

\footnotetext{
* Corresponding author.

E-mail address: li_arantes@yahoo.com.br (L.A. Camargo).
} 

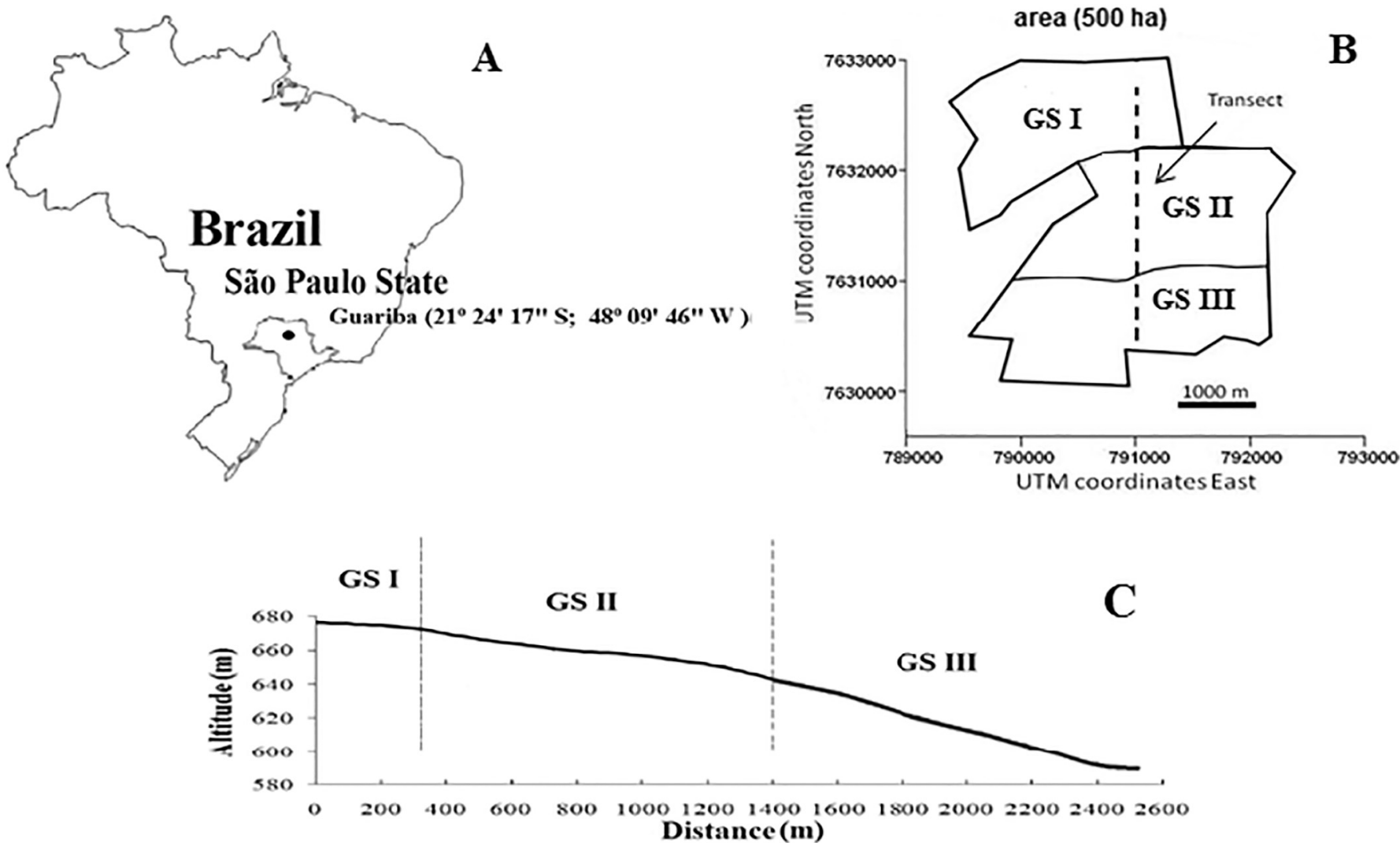

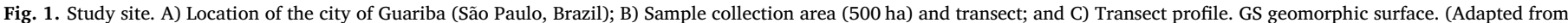
Camargo et al., 2015).

Table 1

Physical and chemical properties of the soil profile in each geomorphic surface (GS) (Adapted from Camargo et al., 2014 and 2016).

\begin{tabular}{|c|c|c|c|c|c|c|c|c|c|c|c|c|c|c|c|c|c|c|c|}
\hline \multirow[t]{2}{*}{ Profile } & \multirow{2}{*}{$\begin{array}{l}\text { Depth } \\
\mathrm{m}\end{array}$} & \multirow[t]{2}{*}{ Horizon } & \multirow{2}{*}{$\begin{array}{l}\text { Color } \\
\text { Moisture }\end{array}$} & \multicolumn{2}{|l|}{$\mathrm{pH}$} & \multirow{2}{*}{$\frac{\mathrm{OM}}{\mathrm{g} \mathrm{kg}^{-1}}$} & \multirow{2}{*}{\multicolumn{2}{|c|}{$\begin{array}{l}\mathrm{Ca} \quad \mathrm{Mg} \\
\mathrm{mmol}_{\mathrm{c}} \mathrm{kg}^{-1}\end{array}$}} & \multirow[t]{2}{*}{$\mathrm{K}$} & \multirow[t]{2}{*}{ SB } & \multirow[t]{2}{*}{ CEC } & \multirow{2}{*}{$\begin{array}{l}\mathrm{V} \\
\%\end{array}$} & \multirow{2}{*}{\multicolumn{2}{|c|}{$\begin{array}{l}\text { CS FS } \\
\mathrm{g} \mathrm{kg}^{-1}\end{array}$}} & \multirow[t]{2}{*}{ Silt } & \multirow[t]{2}{*}{ Clay } & \multirow[t]{2}{*}{$\mathrm{S} / \mathrm{C}$} & \multirow{2}{*}{$\frac{\mathrm{Fe}_{2} \mathrm{O}_{3}}{\mathrm{~g} \mathrm{~kg}^{-1}}$} & \multirow[t]{2}{*}{$\mathrm{Al}_{2} \mathrm{O}_{3}$} \\
\hline & & & & $\mathrm{H}_{2} \mathrm{O}$ & $\mathrm{KCl}$ & & & & & & & & & & & & & & \\
\hline \multicolumn{20}{|c|}{ GS I - Typic Hapludox (Soil Survey Staff, 2010) } \\
\hline \multirow[t]{2}{*}{1} & $0-0.15$ & $\mathrm{~A} 1$ & $5 Y R 4 / 6$ & 7.4 & 6.6 & 32.84 & 57.3 & 7.40 & 1.41 & 66.11 & 78.07 & 84.69 & 387 & 262 & 58.5 & 292.5 & 0.20 & 48.1 & 35 \\
\hline & $0.90-1.40$ & Bw2 & 5YR $4 / 4$ & 5.0 & 4.3 & 11.33 & 4.5 & 2.30 & 0.80 & 7.60 & 38.44 & 19.78 & 286 & 284 & 69.5 & 360.5 & 0.19 & 58.1 & 55 \\
\hline \multicolumn{20}{|c|}{ GS II - Typic Hapludox (Soil Survey Staff, 2010) } \\
\hline \multirow[t]{2}{*}{2} & $0-0.20$ & Ap1 & 5YR $4 / 5$ & 6.0 & 4.9 & 19.37 & 16.80 & 5.60 & 1.72 & 24.12 & 51.87 & 46.50 & 307 & 304 & 74.5 & 314.5 & 0.24 & 59.4 & 40 \\
\hline & $1.20-1.60$ & Bw2 & 5YR 4/6 & 5.1 & 4.4 & 10.91 & 1.90 & 1.00 & 3.97 & 6.87 & 37.71 & 18.23 & 328 & 228 & 64.5 & 379.5 & 0.17 & 65.8 & 55 \\
\hline \multicolumn{20}{|c|}{ GS II - Typic Eutrudox (Soil Survey Staff, 2010) } \\
\hline \multirow[t]{2}{*}{3} & $0-0.15$ & Ap1 & 5YR $4 / 4$ & 6.5 & 5.7 & 21.21 & 24.20 & 10.70 & 2.94 & 37.84 & 58.08 & 65.16 & 367 & 298 & 77.5 & 257.5 & 0.30 & 46.9 & 30 \\
\hline & $0.85-1.00$ & Bw2 & 5YR 4/5 & 6.1 & 5.6 & 10.68 & 8.50 & 2.40 & 0.80 & 11.70 & 28.10 & 41.65 & 333 & 269 & 59.5 & 338.5 & 0.18 & 50.6 & 45 \\
\hline \multicolumn{20}{|c|}{ GS III - Typic Eutrudox (Soil Survey Staff, 2010) } \\
\hline \multirow[t]{2}{*}{4} & $0-0.15$ & Ap1 & $2.5 Y R 4 / 6$ & 6.1 & 5.1 & 27.12 & 32.20 & 9.30 & 2.33 & 43.83 & 78.09 & 56.13 & 312 & 192 & 98 & 398 & 0.25 & 82.1 & 50 \\
\hline & $1.00-1.40$ & Bw2 & 2.5YR $5 / 6$ & 6.5 & 5.9 & 9.62 & 18.20 & 2.90 & 0.19 & 21.29 & 39.51 & 53.90 & 264 & 182 & 76 & 478 & 0.16 & 96.2 & 55 \\
\hline
\end{tabular}

$\mathrm{OM}=$ Organic matter, $\mathrm{SB}=$ Sum of bases, $\mathrm{CEC}=$ cation-exchange capacity, $\mathrm{BS}=$ Base saturation, $\mathrm{CS}=$ coarse sand, $\mathrm{FS}=$ fine sand, $\mathrm{S} / \mathrm{C}=$ silt $/ \mathrm{clay}$ ratio.

potential of spectroscopic techniques for PTE prediction has been the subject of some recent reviews (Horta et al., 2015; Shi et al., 2014).

The primary aims of this study were (a) to predict the contents in PTEs ( $\mathrm{Ba}, \mathrm{Co}, \mathrm{Cr}, \mathrm{Cu}, \mathrm{Mn}, \mathrm{Mo}, \mathrm{Ni}, \mathrm{Pb}$ and $\mathrm{Zn}$ ) from iron oxide contents, magnetic susceptibility (MS) and diffuse reflectance spectra (DRS); and (b) to characterize the spatial variability of PTEs in Brazilian Oxisols.

\section{Materials and methods}

\subsection{Study site}

The study site spanned an area of 500 ha under a sugarcane plantation located near Guariba, in the North-East of the São Paulo state in
Brazil (Fig. 1a). One hundred soil samples (Series 1) were collected from depths of $0-25 \mathrm{~cm}$ at $25 \mathrm{~m}$ intervals along a transect spanning three different geomorphic surfaces (GSs) (Daniels et al., 1970; (Fig. 1b). Also, another 206 soil samples (Series 2) were collected from subareas each representing 2.5 ha around the transect in order to predict unknown values.

The most evolved geomorphic surface, GS I, is a depositional surface occupying $400 \mathrm{~m}$ of the hillside; it has slopes of $0-4 \%$ (Fig. 1c) and Typic Hapludox soil (Soil Survey Staff, 2010). The boundary between GS II and GS III is approximately $1400 \mathrm{~m}$ from the top of the hillside. GS II has a gentle slope and its soils are Typic Hapludox and Typic Eutrudox (Soil Survey Staff, 2010). The most recent surface, GS III, has a steeper slope $(7 \%)$ than the other two and Typic Eutrudox soil (Soil 
Table 2

Descriptive statistics for the soil attributes.

\begin{tabular}{|c|c|c|c|c|c|}
\hline & GS & Mean & Minimum & Maximum & CV (\%) \\
\hline \multirow[t]{4}{*}{ Clay $\left(\mathrm{g} \mathrm{kg}^{-1}\right)$} & $\mathrm{I}^{*}$ & $346 b$ & 328 & 377 & 4 \\
\hline & $\mathrm{II}^{* *}$ & $331 b$ & 285 & 390 & 7 \\
\hline & $\mathrm{III}^{* * *}$ & $434 \mathrm{a}$ & 326 & 569 & 16 \\
\hline & Transect $^{* * * * *}$ & 357 & 285 & 569 & 18 \\
\hline \multirow[t]{4}{*}{ Sand $\left(\mathrm{g} \mathrm{kg}^{-1}\right)$} & I & $613 a$ & 584 & 643 & 3 \\
\hline & II & $638 a$ & 570 & 693 & 4 \\
\hline & III & $502 b$ & 298 & 645 & 22 \\
\hline & Transect & 578 & 298 & 693 & 16 \\
\hline \multirow[t]{4}{*}{$\mathrm{OM}\left(\mathrm{g} \mathrm{kg}^{-1}\right)$} & I & $27 \mathrm{a}$ & 21 & 43 & 16 \\
\hline & II & $25 a$ & 18 & 37 & 20 \\
\hline & III & $29 a$ & 22 & 38 & 14 \\
\hline & Transect & 27 & 18 & 43 & 17 \\
\hline \multirow[t]{4}{*}{$\mathrm{pH}$} & I & $5.9 \mathrm{a}$ & 5.2 & 6.5 & 6 \\
\hline & II & $5.3 \mathrm{~b}$ & 4.6 & 6.0 & 5 \\
\hline & III & $5.2 \mathrm{~b}$ & 4.4 & 6.2 & 5 \\
\hline & Transect & 5.4 & 4.4 & 6.5 & 9 \\
\hline \multirow[t]{4}{*}{$\mathrm{CEC}\left(\mathrm{mmol}_{\mathrm{c}} \mathrm{kg}^{-1}\right)$} & I & $74 a$ & 60 & 97 & 11 \\
\hline & II & $61 b$ & 52 & 77 & 9 \\
\hline & III & $67 a b$ & 41 & 95 & 18 \\
\hline & Transect & 66 & 41 & 97 & 15 \\
\hline \multirow[t]{4}{*}{ Fed $\left(\mathrm{g} \mathrm{kg}^{-1}\right)$} & I & $40.2 b$ & 26.8 & 44.8 & 10 \\
\hline & II & $37.7 \mathrm{~b}$ & 27.9 & 50.3 & 13 \\
\hline & III & $65.1 \mathrm{a}$ & 39.6 & 100.2 & 25 \\
\hline & Transect & 51.0 & 26.9 & 100.2 & 34 \\
\hline \multirow[t]{4}{*}{ Feo $\left(\mathrm{g} \mathrm{kg}^{-1}\right)$} & I & $5.4 \mathrm{~b}$ & 2.2 & 7.4 & 20 \\
\hline & II & $5.2 \mathrm{~b}$ & 2.6 & 9.0 & 20 \\
\hline & III & $6.7 \mathrm{a}$ & 3.1 & 9.6 & 22 \\
\hline & Transect & 5.8 & 2.2 & 9.6 & 22 \\
\hline \multirow[t]{4}{*}{$\mathrm{Gt}\left(\mathrm{g} \mathrm{kg}^{-1}\right)$} & I & $17.3 \mathrm{~b}$ & 9.6 & 23.1 & 19 \\
\hline & II & $16.3 \mathrm{~b}$ & 7.9 & 20.8 & 20 \\
\hline & III & $21.1 \mathrm{a}$ & 6.9 & 55.7 & 67 \\
\hline & Transect & 18.4 & 6.9 & 55.7 & 50 \\
\hline \multirow[t]{4}{*}{$\mathrm{Hm}\left(\mathrm{g} \mathrm{kg}^{-1}\right)$} & I & $33.9 b$ & 22.7 & 40.3 & 11 \\
\hline & II & $31.5 b$ & 16.7 & 50.8 & 22 \\
\hline & III & $66.5 \mathrm{a}$ & 38.8 & 99.4 & 22 \\
\hline & Transect & 47.9 & 16.7 & 99.4 & 43 \\
\hline \multirow[t]{4}{*}{ MS $\left(10^{-6} \mathrm{~m}^{3} \mathrm{~kg}^{-1}\right)$} & I & $2.1 \mathrm{~b}$ & 1.84 & 3.63 & 21 \\
\hline & II & $2.8 \mathrm{~b}$ & 1.38 & 4.97 & 39 \\
\hline & III & $9.4 \mathrm{a}$ & 5.00 & 22.72 & 52 \\
\hline & Transect & 5.4 & 1.38 & 22.72 & 87 \\
\hline \multirow[t]{4}{*}{$\mathrm{Gb} /(\mathrm{Gb}+\mathrm{Kt})$} & I & $0.22 b$ & 0.18 & 0.26 & 11 \\
\hline & II & $0.29 b$ & 0.16 & 0.49 & 26 \\
\hline & III & $0.41 \mathrm{a}$ & 0.34 & 0.54 & 14 \\
\hline & Transect & 0.33 & 0.16 & 0.54 & 30 \\
\hline
\end{tabular}

GS geomorphic surface, CV coefficient of variation. Means of the same attribute followed by the same letter were not significantly different as per Tukey's test at the $5 \%$ probability level.

$$
\begin{aligned}
& { }^{*} N=21 . \\
& { }^{* *} N=39 . \\
& { }^{* * *} N=40 . \\
& { }^{* * * *} N=100 .
\end{aligned}
$$

Survey Staff, 2010). Table 1 shows the representative profiles for each soil. The soils evolved from sandstones in the Bauru Group, Adamantina Formation. Further details about the experimental site can be found elsewhere (Camargo et al., 2014, 2015).

\subsection{Laboratory analyses}

The soil samples were subjected to grain-size analysis according to Day (1965). $\mathrm{pH}$ was measured potentiometrically in 1:2.5 soil: $0.01 \mathrm{~mol} \mathrm{~L}^{-1} \mathrm{CaCl}_{2}$ suspensions (Raij et al., 1987) and exchangeable cations were extracted by passage through an ionic exchange resin (Raij et al., 2001). The analytical results were used to calculate the sum of bases (SB) and the cation-exchange capacity (CEC) of the soils. Organic carbon was quantified by oxidation and the organic matter (OM) content estimated by multiplying the organic carbon concentration by a factor of 1.724 (Jackson, 1985).

Potentially toxic elements were extracted by using USEPA method

\begin{tabular}{|c|c|c|c|c|c|}
\hline & GS & Mean & Minimum & Maximum & CV (\%) \\
\hline & & \multicolumn{4}{|c|}{$\mathrm{mg} \mathrm{kg}^{-1}$} \\
\hline \multirow[t]{4}{*}{$\mathrm{Ba}$} & $I^{*}$ & $22.8 \mathrm{~b}$ & 14.3 & 65 & 56 \\
\hline & $\mathrm{II}^{* *}$ & $19.4 \mathrm{~b}$ & 10.9 & 58.7 & 47 \\
\hline & $\mathrm{III}^{* * *}$ & $111.3 \mathrm{a}$ & 54.1 & 237.8 & 45 \\
\hline & Transect ${ }^{* * * * *}$ & 58.1 & 10.9 & 237.8 & 96 \\
\hline \multirow[t]{4}{*}{ Co } & I & $2.6 \mathrm{~b}$ & 2.1 & 3.7 & 14 \\
\hline & II & $3.8 \mathrm{~b}$ & 2.4 & 5.1 & 22 \\
\hline & III & $6.5 a$ & 4.3 & 10.4 & 27 \\
\hline & Transect & 4.5 & 2.1 & 10.4 & 46 \\
\hline \multirow[t]{4}{*}{$\mathrm{Cr}$} & I & $67.4 \mathrm{a}$ & 46.1 & 136.6 & 30 \\
\hline & II & $64.6 \mathrm{a}$ & 44.1 & 88.2 & 14 \\
\hline & III & $55.3 \mathrm{~b}$ & 42.8 & 73.30 & 11 \\
\hline & Transect & 61.3 & 42.8 & 136.6 & 20 \\
\hline \multirow[t]{4}{*}{$\mathrm{Cu}$} & I & $1.9 \mathrm{~b}$ & 1.5 & 3.8 & 27 \\
\hline & II & $1.9 \mathrm{~b}$ & 1.6 & 2.4 & 10 \\
\hline & III & $2.9 \mathrm{a}$ & 2.0 & 4.1 & 16 \\
\hline & Transect & 2.3 & 1.5 & 4.1 & 26 \\
\hline \multirow[t]{4}{*}{ Mn } & I & $141.8 \mathrm{c}$ & 118.9 & 204.4 & 14 \\
\hline & II & $210.0 \mathrm{~b}$ & 112.8 & 521.3 & 50 \\
\hline & III & $460.8 \mathrm{a}$ & 285.0 & 622.0 & 19 \\
\hline & Transect & 300.5 & 112.8 & 622.0 & 54 \\
\hline \multirow[t]{4}{*}{ Mo } & I & $1.0 \mathrm{a}$ & 0.5 & 4.2 & 84 \\
\hline & II & $0.5 \mathrm{~b}$ & 0.3 & 1.1 & 31 \\
\hline & III & $0.5 b$ & 0.1 & 1.0 & 47 \\
\hline & Transect & 0.6 & 0.1 & 4.2 & 75 \\
\hline \multirow[t]{4}{*}{$\mathrm{Ni}$} & I & $4.5 \mathrm{~b}$ & 3.5 & 5.5 & 15 \\
\hline & II & $5.3 \mathrm{~b}$ & 4.0 & 7.6 & 15 \\
\hline & III & $9.5 a$ & 5.6 & 15.9 & 27 \\
\hline & Transect & 6.9 & 5.6 & 15.9 & 41 \\
\hline \multirow[t]{4}{*}{$\mathrm{Pb}$} & I & $16.6 \mathrm{a}$ & 7.8 & 68.0 & 89 \\
\hline & II & $10.4 b$ & 7.7 & 14.6 & 15 \\
\hline & III & $15.0 \mathrm{a}$ & 10.5 & 24.7 & 20 \\
\hline & Transect & 13.5 & 7.7 & 68.0 & 53 \\
\hline \multirow[t]{4}{*}{$\mathrm{Zn}$} & I & $26.3 \mathrm{~b}$ & 13.5 & 98.4 & 76 \\
\hline & II & $20.9 b$ & 13.6 & 53.2 & 40 \\
\hline & III & $40.9 \mathrm{a}$ & 25.7 & 66.6 & 31 \\
\hline & Transect & 30.2 & 13.5 & 98.4 & 52 \\
\hline
\end{tabular}
3051A (United States Environmental Protection Agency - USEPA,
Table 3

Descriptive statistics for the target PTEs.

GS geomorphic surface, CV coefficient of variation. Means of the same attribute followed by the same letter were not significantly different as per Tukey's test at the $5 \%$ probability level.

${ }^{*} N=21$.

*** $N=39$.

**** $N=40$.

***** $N=100$

1996), which involves attacking samples with concentrated acid in a microwave oven under controlled temperature and pressure conditions. Inductively coupled plasma-optical emission spectroscopy (ICP-OES) was used to determine PTEs (Ba, Co, $\mathrm{Cr}, \mathrm{Cu}, \mathrm{Mn}, \mathrm{Mo}, \mathrm{Ni}, \mathrm{Pb}$ and $\mathrm{Zn}$ ) in the resulting extracts. The digestion method used does not afford dissolution of silicate minerals but can extract elements adsorbed to iron and aluminium oxides, thus allowing a semi-total PTE content to be estimated.

The contents in iron oxides extracted by sodium dithionite-citrate-bicarbonate (Fed) at $25{ }^{\circ} \mathrm{C}$ for $16 \mathrm{~h}$ were determined according to Mehra and Jackson (1960), whereas those in iron oxides extracted by acid ammonium oxalate (Feo) were quantified according to McKeague and Day (1966).

Powder X-ray diffraction spectroscopy was used to determine hematite $(\mathrm{Hm})$ and goethite $(\mathrm{Gt})$ after concentration by boiling the clay fraction in $\mathrm{NaOH}$ (Norrish and Taylor, 1961). Also, the gibbsite/ (gibbsite + kaolinite) $[\mathrm{Gb} /(\mathrm{Gb}+\mathrm{Kt})]$ ratio was estimated by removing iron oxides from the clay fraction according to Mehra and Jackson (1960). Powder XRD patterns were recorded at a scan speed of $1^{\circ} 2 \theta$ / min on a Mini-Flex Rigaku II spectrometer (20 mA, $30 \mathrm{kV})$ using $\mathrm{Cu} \mathrm{K \alpha}$ radiation. The $\mathrm{Hm} / \mathrm{Gt}$ ratio was estimated by comparing the peak areas obtained from the $\mathrm{Hm} / \mathrm{Gt}$ XRD tracing ratio with the ratios for $\mathrm{Gt}-\mathrm{Hm}$ 
Table 4

Pearson's correlation coefficients between PTEs and soil attributes.

\begin{tabular}{|c|c|c|c|c|c|c|c|c|c|c|c|}
\hline & Sand & Clay & $\mathrm{OM}$ & $\mathrm{pH}$ & CEC & Fed & Feo & $\mathrm{Gt}$ & $\mathrm{Hm}$ & MS & $\mathrm{Gb} /(\mathrm{Gb}+\mathrm{Kt})$ \\
\hline $\mathrm{Ba}$ & $-0.90^{* *}$ & $0.90^{* *}$ & $0.27^{*}$ & $-0.23^{*}$ & $0.28^{*}$ & $0.87^{* *}$ & $0.53^{* *}$ & $0.17^{\mathrm{NS}}$ & $0.78^{* *}$ & $0.92^{* *}$ & $0.75^{* *}$ \\
\hline Co & $-0.85^{* *}$ & $0.85^{* *}$ & $0.16^{\mathrm{NS}}$ & $-0.34^{* *}$ & $0.21^{\mathrm{NS}}$ & $0.86^{* *}$ & $0.50^{* *}$ & $0.20^{\mathrm{NS}}$ & $0.78^{* * *}$ & $0.92^{* *}$ & $0.86^{* *}$ \\
\hline $\mathrm{Cr}$ & $0.25^{*}$ & $-0.28^{*}$ & $-0.01^{\mathrm{NS}}$ & $0.28^{* *}$ & $0.02^{\mathrm{NS}}$ & $-0.27^{\mathrm{NS}}$ & $-0.21^{\mathrm{NS}}$ & $-0.08^{\mathrm{NS}}$ & $-0.17^{\mathrm{NS}}$ & $-0.27^{*}$ & $-0.19^{\mathrm{NS}}$ \\
\hline $\mathrm{Cu}$ & $-0.70^{* *}$ & $0.70^{* *}$ & $0.30^{* *}$ & $-0.35^{* *}$ & $0.24^{*}$ & $0.76^{* * *}$ & $0.54^{* * *}$ & $0.11^{\mathrm{NS}}$ & $0.73^{* *}$ & $0.72^{* *}$ & $0.66^{* *}$ \\
\hline Mn & $-0.64^{* *}$ & $0.69^{* *}$ & $0.07^{\mathrm{NS}}$ & $-0.20^{\mathrm{NS}}$ & $0.01^{\mathrm{NS}}$ & $0.73^{* * *}$ & $0.31^{* * *}$ & $0.04^{\mathrm{NS}}$ & $0.80^{* *}$ & $0.80^{* *}$ & $0.84^{* *}$ \\
\hline Mo & $0.18^{\mathrm{NS}}$ & $-0.20^{\mathrm{NS}}$ & $0.02^{\mathrm{NS}}$ & $0.12^{\mathrm{NS}}$ & $0.13^{\mathrm{NS}}$ & $-0.22^{\mathrm{NS}}$ & $-0.18^{\mathrm{NS}}$ & $-0.15^{\mathrm{NS}}$ & $-0.18^{\mathrm{NS}}$ & $-0.26^{*}$ & $-0.47^{* *}$ \\
\hline $\mathrm{Ni}$ & $-0.62^{* *}$ & $0.64^{* *}$ & $0.12^{\mathrm{NS}}$ & $-0.36^{* *}$ & $0.16^{\mathrm{NS}}$ & $0.73^{* * *}$ & $0.45^{* *}$ & $0.06^{\mathrm{NS}}$ & $0.77^{* * *}$ & $0.71^{* * *}$ & $0.75^{* * *}$ \\
\hline $\mathrm{Pb}$ & $0.24^{*}$ & $0.25^{*}$ & $0.06^{\mathrm{NS}}$ & $0.20^{\mathrm{NS}}$ & $0.22^{\mathrm{NS}}$ & $0.22^{\mathrm{NS}}$ & $0.25^{*}$ & $-0.10^{\mathrm{NS}}$ & $0.25^{*}$ & $0.18^{\mathrm{NS}}$ & $0.41^{* *}$ \\
\hline $\mathrm{Zn}$ & $-0.71^{* *}$ & $0.68^{* *}$ & $0.34^{* *}$ & $-0.08^{\mathrm{NS}}$ & $0.39^{* * *}$ & $0.70^{* *}$ & $0.48^{* *}$ & $0.04^{\mathrm{NS}}$ & $0.65^{* *}$ & $0.73^{* *}$ & $0.60^{* *}$ \\
\hline
\end{tabular}

NS not significant.

$(N=100)$.

* Significant at $p<0.05$.

*** Significant at $p<0.01$.
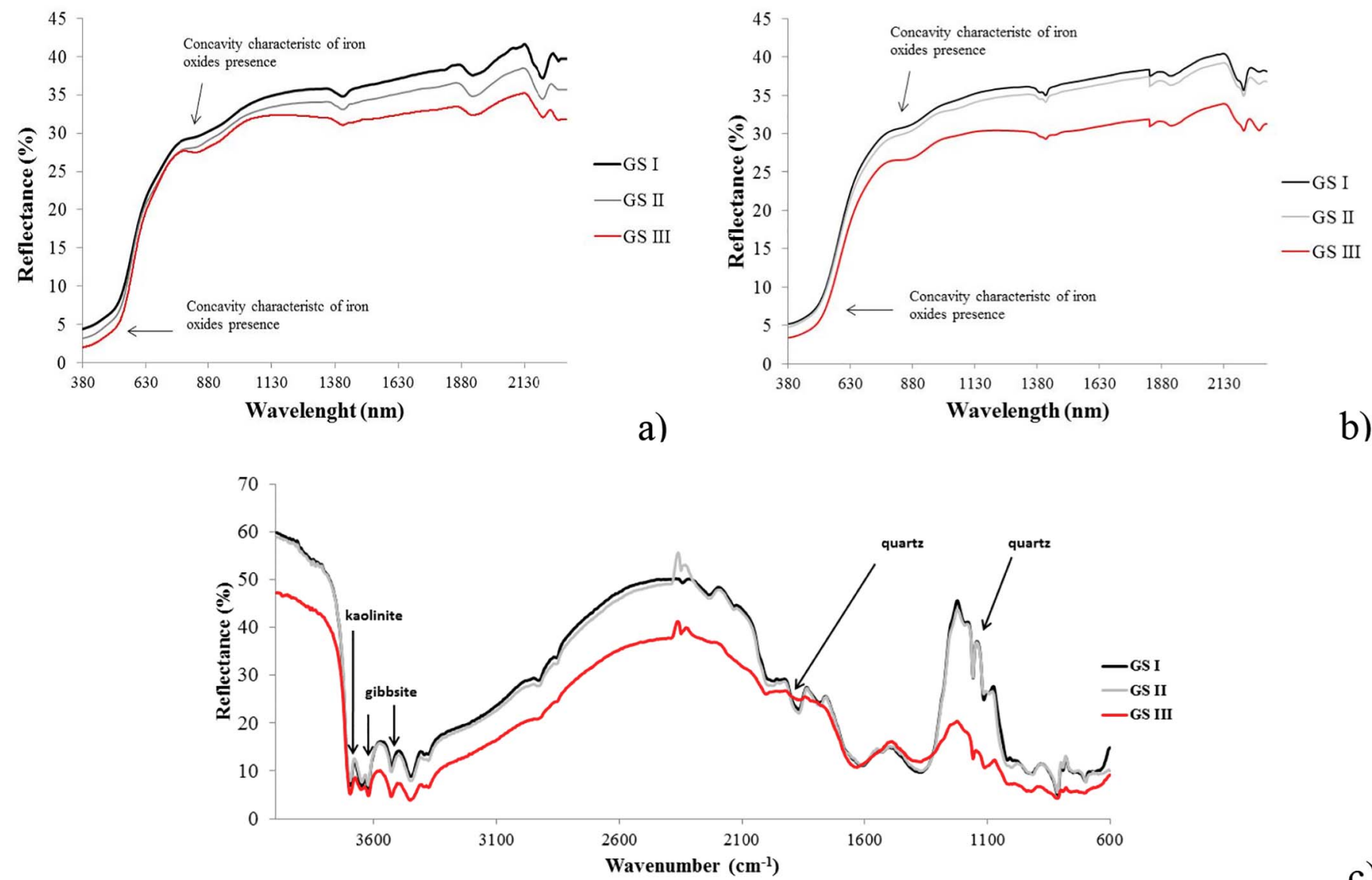

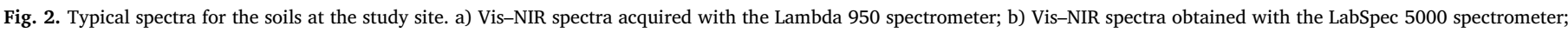
and c) MIR spectra acquired with the Tensor 27 spectrometer.

standard mixtures. The proportions of $\mathrm{Hm}$ and Gt were calculated by assigning them the difference between Fed and Feo. Finally, the Gb/ $(\mathrm{Gb}+\mathrm{Kt})$ ratio was obtained from the areas under the reflection peaks 002 for $\mathrm{Gb}$ and 001 for Kt.

Soil samples were ground to $<2 \mathrm{~mm}$ in an agate mortar for DRS analysis. Samples were scanned in the visible (Vis), near-infrared (NIR) and mid-infrared (MIR) ranges (380-16,666 nm), using the following equipment: (a) a Perkin Elmer Lambda 950 spectrophotometer equipped with an integrating sphere to scan the wavelength range $380-2300 \mathrm{~nm}$ at $1 \mathrm{~nm}$ intervals; (b) a LabSpec 5000 ASD $^{\circledR}$ Vis-NIR spectrophotometer equipped with a manual probe consisting of a lamp and fibre optics for acquisition of reflected radiation to scan the previous range with the same resolution; and (c) a Bruker Optics Tensor 27
MIR spectrophotometer equipped with a Pike EasiDiff reflectance hemisphere to scan the wavenumber range $4000-600 \mathrm{~cm}^{-1}$ (2500-16,666 nm as wavelength) at $8 \mathrm{~cm}^{-1}$ intervals 64 times each second. Teflon (PTFE) and potassium bromide (KBr) were used as spectral references for the Vis-NIR and MIR range, respectively.

Low-frequency $(0.47 \mathrm{kHz})$ magnetic susceptibility measurements of air-dried soil samples were made with an MS2 meter from Bartington Instruments coupled to a two-frequency MS2B laboratory sensor.

\subsection{Statistical analysis}

The data for the transect samples (Series 1) were analysed by using descriptive statistics to calculate means, maxima, minima and 
Table 5

MLR-based calibrated models for PTE prediction.

\begin{tabular}{lll}
\hline Models & & $\mathrm{R}^{2}$ \\
\hline 1 & $\mathrm{Ba}=10.44 \times \mathrm{MS}-2.02$ & 0.88 \\
2 & $\mathrm{Ba}=5.86 \times \mathrm{MS}+0.37 \times$ clay -113.72 & 0.90 \\
3 & $\mathrm{Ba}=5.71 \times \mathrm{MS}+0.45 \times$ clay $-5.00 \times \mathrm{Fed}-110.56$ & 0.91 \\
4 & $\mathrm{Co}=0.38 \times \mathrm{MS}+2.52$ & 0.85 \\
5 & $\mathrm{Co}=0.25 \times \mathrm{MS}+0.010 \times$ clay -0.95 & 0.87 \\
6 & $\mathrm{Co}=0.24 \times \mathrm{MS}+0.01 \times$ clay $-0.33 \times \mathrm{Fed}-0.39$ & 0.89 \\
7 & $\mathrm{Cu}=0.03 \times \mathrm{Fed}+1.03$ & 0.58 \\
8 & $\mathrm{Cu}=0.02 \times \mathrm{Fed}+0.01 \times \mathrm{Hm}+1.08$ & 0.62 \\
9 & $\mathrm{Mn}=24.32 \times \mathrm{MS}+166.20$ & 0.66 \\
10 & $\mathrm{Mn}=29.76 \times \mathrm{MS}-353.97 \times \mathrm{Fed}+353.97$ & 0.72 \\
11 & $\mathrm{Ni}=2.00 \times \mathrm{MS}+3.19$ & 0.73 \\
12 & $\mathrm{Ni}=1.28 \times \mathrm{MS}+0.21 \times \mathrm{Hm}-2.46$ & 0.75 \\
13 & $\mathrm{Ni}=0.53 \times \mathrm{MS}+0.20 \times \mathrm{Hm}+0.27 \times \mathrm{Fed}-11.01$ & 0.77 \\
14 & $\mathrm{Zn}=2.38 \times \mathrm{MS}+17.87$ & 0.55 \\
\hline
\end{tabular}

$R^{2}$ Coefficient of determination.

Table 6

Summary of the results obtained by PLSR of the target soil attributes. Data were obtained using Lambda 950 Vis/NIR, LabSpec 5000 Vis/NIR and Tensor 27 MIR spectrophotometers.

\begin{tabular}{|c|c|c|c|c|c|c|c|c|c|c|}
\hline & \multicolumn{10}{|c|}{ Lambda 950 Vis/NIR spectrophotometer } \\
\hline & \multicolumn{5}{|c|}{ Vis $(380-800 \mathrm{~nm})$} & \multicolumn{5}{|c|}{ Vis + NIR (380-2300 nm) } \\
\hline & \multirow[t]{2}{*}{$\mathrm{F}^{\mathrm{a}}$} & \multicolumn{4}{|c|}{ Cross-validation } & \multirow[t]{2}{*}{$\mathrm{F}^{\mathrm{a}}$} & \multicolumn{4}{|c|}{ Cross-validation } \\
\hline & & $\mathrm{R}_{\mathrm{adj} .}^{2}$ & SDE & RMSE & RPD & & $\mathrm{R}_{\mathrm{adj} .}^{2}$ & SDE & RMSE & RPD \\
\hline $\mathrm{Ba}$ & 14 & 0.78 & 25.6 & 25.4 & 2.1 & 13 & 0.81 & 23.6 & 23.5 & 2.3 \\
\hline Co & 7 & 0.83 & 0.4 & 0.4 & 2.5 & 14 & 0.89 & 0.7 & 0.7 & 3.0 \\
\hline $\mathrm{Cu}$ & 15 & 0.62 & 0.4 & 0.4 & 1.6 & 7 & 0.69 & 0.3 & 0.3 & 1.8 \\
\hline Mn & 15 & 0.86 & 59.8 & 59.5 & 2.7 & 7 & 0.86 & 59.5 & 59.2 & 2.8 \\
\hline $\mathrm{Ni}$ & 15 & 0.75 & 5.9 & 5.9 & 2.0 & 15 & 0.71 & 6.4 & 6.3 & 1.9 \\
\hline $\mathrm{Zn}$ & 6 & 0.40 & 12.5 & 12.4 & 1.3 & 9 & 0.41 & 12.3 & 12.2 & 1.3 \\
\hline
\end{tabular}

LabSpec 5000 Vis/NIR spectrophotometer

\begin{tabular}{|c|c|c|c|c|c|c|c|c|c|c|}
\hline & \multicolumn{5}{|c|}{ Vis $(380-800 \mathrm{~nm})$} & \multicolumn{5}{|c|}{ Vis + NIR $(380-2500 \mathrm{~nm})$} \\
\hline & \multirow[t]{2}{*}{$\mathrm{F}^{\mathrm{a}}$} & \multicolumn{4}{|c|}{ Cross-validation } & \multirow[t]{2}{*}{$\mathrm{F}^{\mathrm{a}}$} & \multicolumn{4}{|c|}{ Cross-validation } \\
\hline & & $\mathrm{R}_{\mathrm{adj} .}^{2}$ & SDE & RMSE & RPD & & $\mathrm{R}_{\text {adj. }}^{2}$ & SDE & RMSE & RPD \\
\hline $\mathrm{Ba}$ & 5 & 0.70 & 29.5 & 29.4 & 1.9 & 6 & 0.79 & 24.9 & 24.8 & 2.2 \\
\hline Co & 6 & 0.80 & 0.9 & 0.9 & 2.3 & 7 & 0.87 & 0.7 & 0.7 & 2.9 \\
\hline $\mathrm{Cu}$ & 4 & 0.60 & 0.4 & 0.4 & 1.6 & 9 & 0.71 & 0.3 & 0.3 & 1.8 \\
\hline Mn & 5 & 0.80 & 71.2 & 70.8 & 2.3 & 8 & 0.91 & 47.9 & 47.8 & 3.4 \\
\hline $\mathrm{Ni}$ & 4 & 0.59 & 7.6 & 7.5 & 1.6 & 5 & 0.65 & 6.9 & 6.9 & 1.7 \\
\hline $\mathrm{Zn}$ & 3 & 0.34 & 12.8 & 12.7 & 1.2 & 4 & 0.42 & 12.1 & 12.1 & 1.3 \\
\hline
\end{tabular}

Tensor 27 MIR spectrophotometer

MIR (2500 to $16,666 \mathrm{~nm}$ )

$\mathrm{F}^{\mathrm{a}} \quad$ Cross-validation

\begin{tabular}{llllll} 
& $\mathrm{F}^{\mathrm{a}}$ & \multicolumn{3}{l}{ Cross-validation } & \\
\cline { 3 - 6 } & & $\mathrm{R}_{\text {adj. }}^{2}$ & $\mathrm{SDE}$ & $\mathrm{RMSE}$ & $\mathrm{RPD}$ \\
\hline $\mathrm{Ba}$ & 15 & 0.91 & 16.3 & 16.1 & 3.4 \\
$\mathrm{Co}$ & 14 & 0.90 & 0.6 & 0.6 & 3.2 \\
$\mathrm{Cu}$ & 6 & 0.69 & 0.3 & 0.3 & 1.8 \\
$\mathrm{Mn}$ & 15 & 0.94 & 39.0 & 39.2 & 4.2 \\
$\mathrm{Ni}$ & 8 & 0.66 & 6.9 & 6.9 & 1.7 \\
$\mathrm{Zn}$ & 10 & 0.49 & 11.7 & 11.6 & 1.3 \\
\hline
\end{tabular}

a Number of PLSR factors used in the model; $R_{\text {adj }}^{2}$ adjusted coefficient of determination; SDE standard deviation of the distribution error; RPD residual prediction deviation; RMSE root mean square error. coefficients of variation. Pearson's correlation coefficients between PTEs contents and soil attributes were also calculated, and means compared through Tukey's test at the 5\% probability level.

PTEs prediction models were calibrated by applying multiple linear regression (MLR) to the data for Series 1 and partial least-squares regression (PLSR) to the DRS spectra for Series 1 samples (Geladi and Kowalski, 1986). The accuracy of MLR calibrations was evaluated from the coefficient of determination $\left(R^{2}\right)$. Reflectance measurements were converted into absorbance data $\left[\log _{10}\right.$ (1/Reflectance)] for chemometric calibrations based on leave-one-out cross-validation, and a mean-centring pretreatment was applied over all studied ranges. PLSR was implemented by using the software ParLeS ${ }^{\circledR}$ (Viscarra-Rossel, 2008) and the accuracy of PLSR calibration assessed in terms of the adjusted coefficient of determination $\left(R_{\text {adj }}^{2}\right)$, standard deviation error (SDE) and residual prediction deviation (RPD), the last being calculated as the ratio of the standard deviation (SD) to the root mean square error (RMSE) for the residuals of the original data.

The influence of a given attribute on the PLSR prediction of another is usually assessed through the "variable importance in the projection" (VIP) (Wold et al., 2001; Yan et al., 2013). Thus, variables identified as being the most important in explaining the prediction of a given attribute correspond to the strongest peaks in VIP plots. "Unknown" PTEs values were predicted by applying MLR- and PLSR-calibrated models to Series 2 samples.

Thereafter, the spatial dependence of PTE contents, both observed and predicted by the calibrated models, was assessed from experimental semivariograms. On the assumption that the function for the intrinsic hypothesis was stationary (Vieira, 2000), the semivariograms were estimated from

$\hat{\gamma}(h)=\frac{1}{2 N(h)} \sum_{i=1}^{N(h)}\left[Z\left(x_{i}\right)-Z\left(x_{i}+h\right)\right]^{2}$

where $\hat{\gamma}(h)$ is the semivariance within a distance $h, N(h)$ the number of point pairs $\left[Z\left(x_{i}\right), Z\left(x_{i}+h\right)\right]$ within such a distance and $x_{i}$ the spatial position of the variable $Z$. The experimental semivariogram was thus a plot of $\hat{\gamma}(h)$ against $h$. Fitting a mathematical model to each experimental semivariogram allowed the theoretical model coefficients for the semivariograms [viz., nugget effect $\left(C_{0}\right)$, sill $\left(C_{0}+C_{1}\right)$, and range (a)] to be estimated.

The best-fitted model was chosen in terms of the least residual sum of squares (RSS), the coefficient of determination $\left(R^{2}\right)$ and the crossvalidation parameters obtained by regressing observed values against predicted values.

An acceptable theoretical model was fit to the experimental semivariogram and used to estimate PTEs contents at non-sampled sites in the study area. Ordinary kriging (OK) was estimated from the following equation:

$\widehat{Z}\left(x_{0}\right)=\sum_{i=1}^{N} \lambda_{i} Z\left(x_{i}\right)$

where $\widehat{Z}\left(x_{0}\right)$ is the estimate at non-sampled point $x_{0}, Z\left(x_{i}\right)$ the observed value at $i(i=1,2 \ldots n)$ and $\lambda_{i}$ the weight of each neighbor in the estimation procedure. By minimizing the variance, kriging provides the best linear unbiased predictions (BLUP) (Oliver and Webster, 2014).

\section{Results and discussion}

\subsection{Soil properties}

The sand, clay and OM contents of the soils spanned the ranges 298-693, 285-569 and 18-43 $\mathrm{g} \mathrm{kg}^{-1}$, respectively (Table 2). $\mathrm{pH}$ ranged from 4.4 to 6.5 and CEC from 41 to $97 \mathrm{mmol}_{\mathrm{c}} \mathrm{kg}^{-1}$ (Table 2). GS III exhibited the highest values of all soil attributes except sand content and $\mathrm{pH}$. The highest Fed, Feo, Gt, and Hm contents, and the highest MS values and $\mathrm{Gb} /(\mathrm{Gb}+\mathrm{Kt})$ ratios, were also found in GS III (Table 2). 


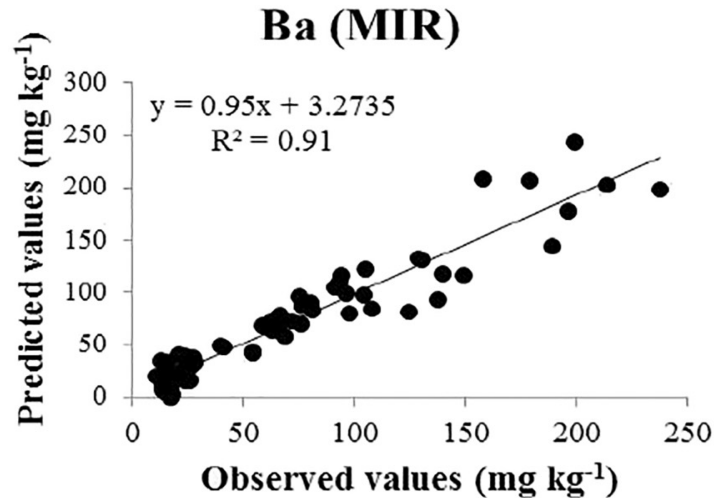

Observed values (mg kg-1)

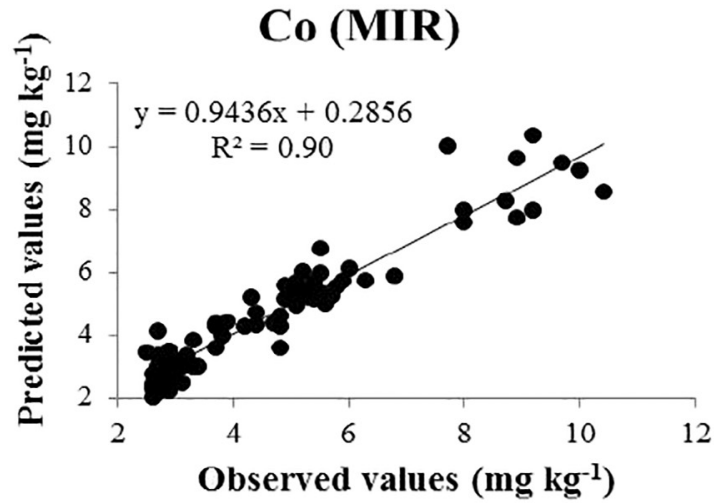

c)
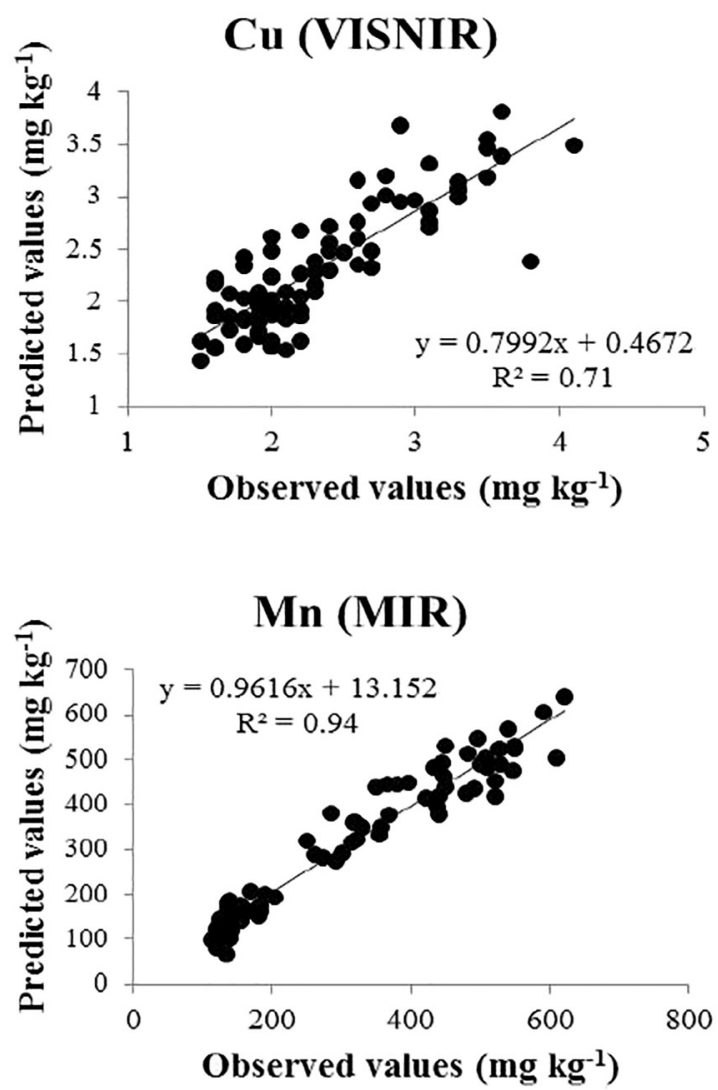

Ba

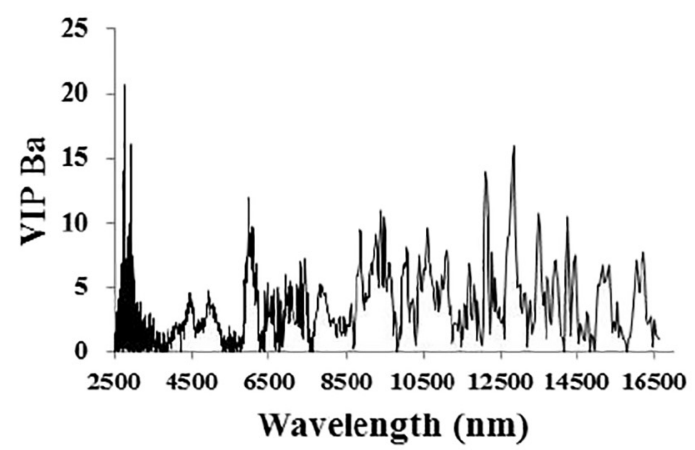

b)

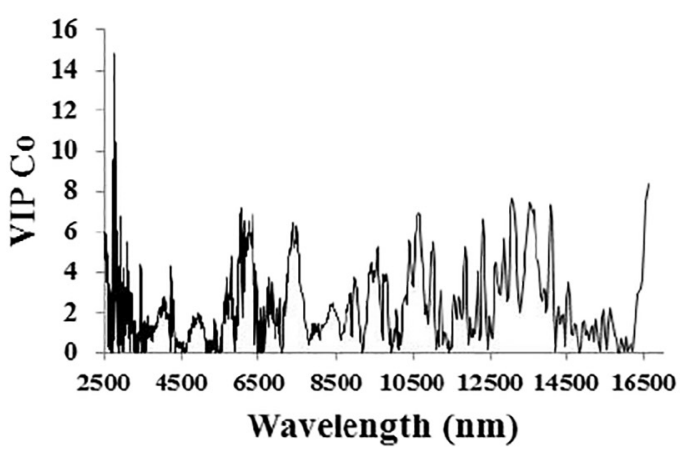

d)

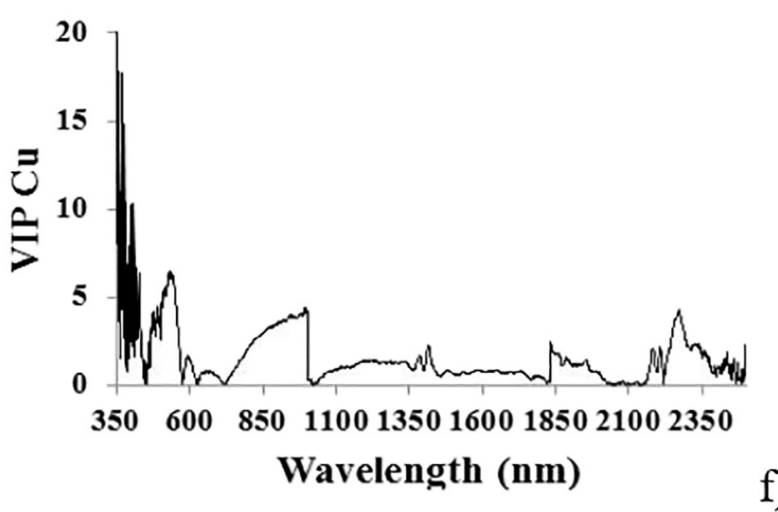

g)

Mn

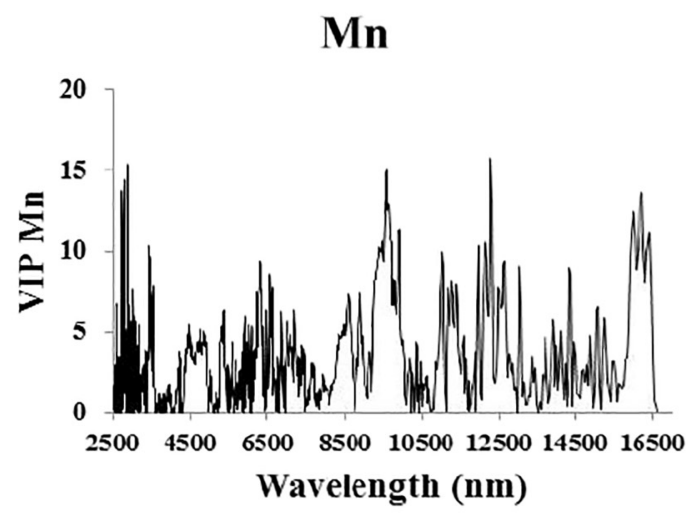

h)

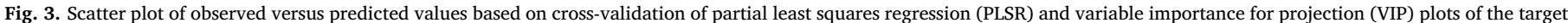

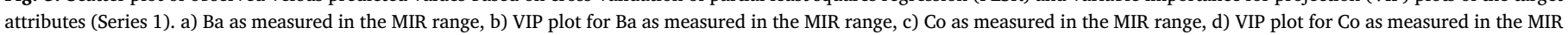

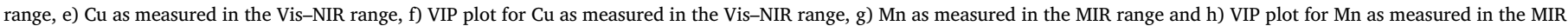
range. 


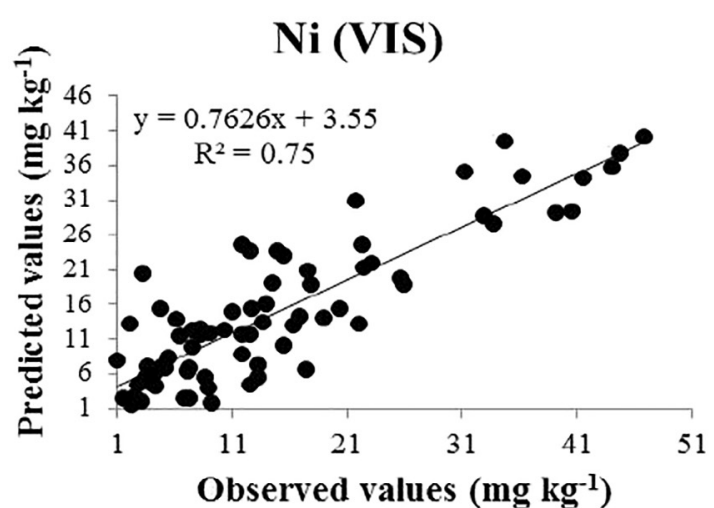

Observed values (mg kg-1)

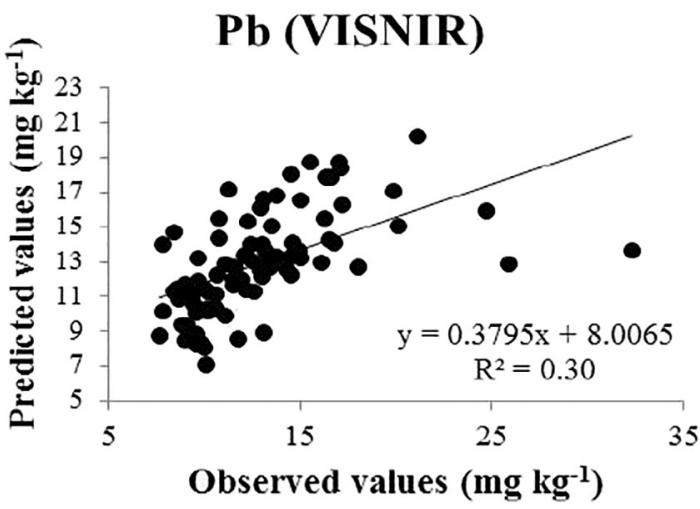

c)

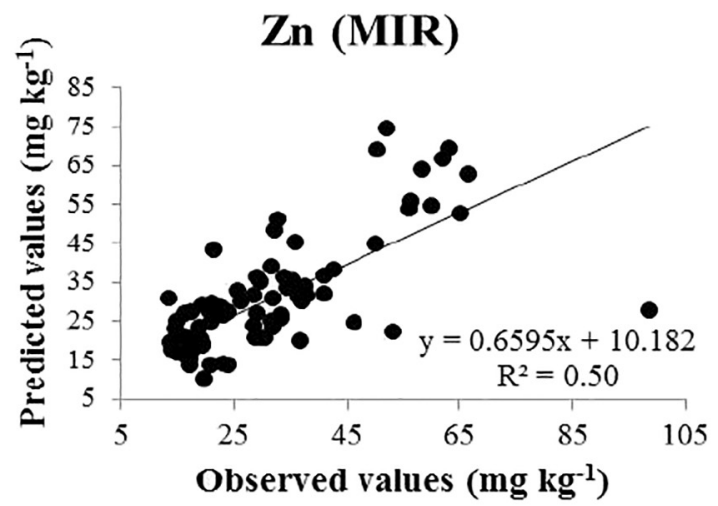

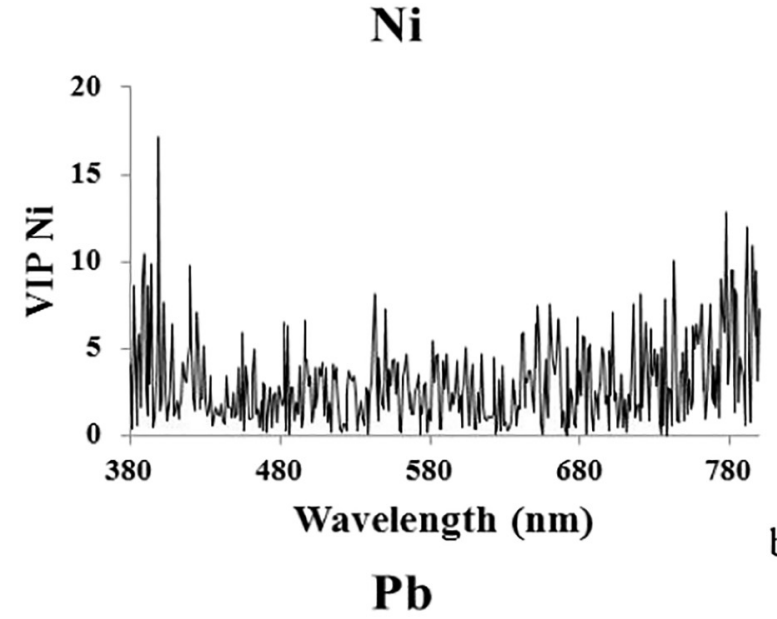

b)

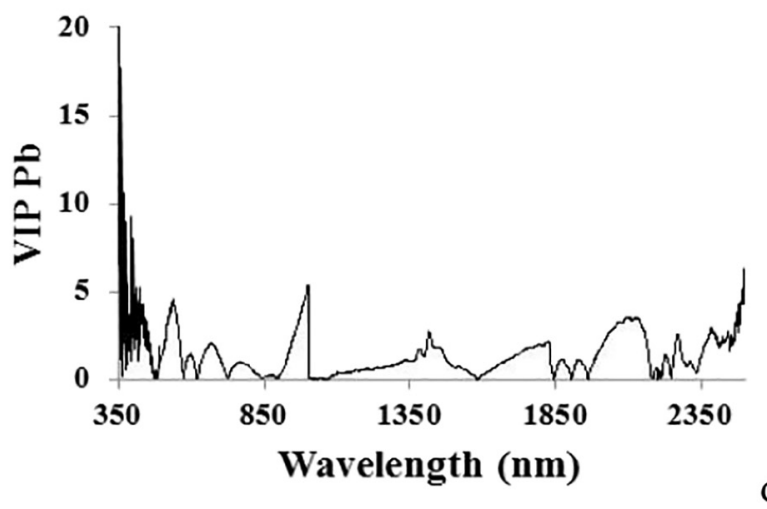

d)

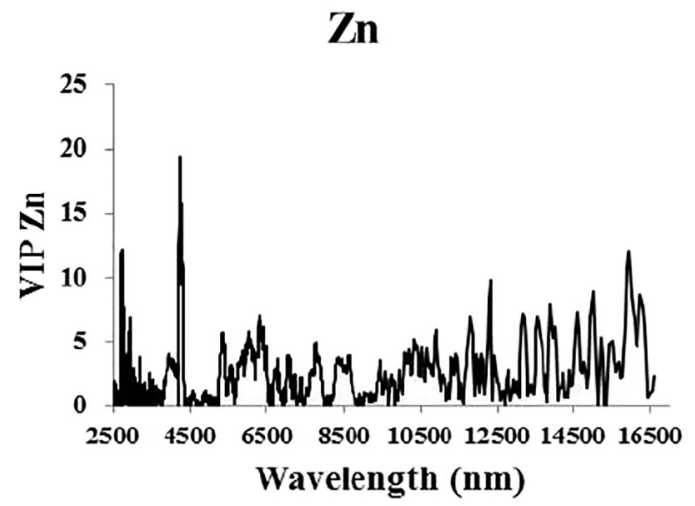

Wavelength (nm)

e)

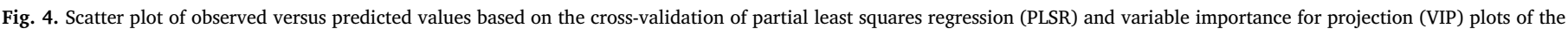

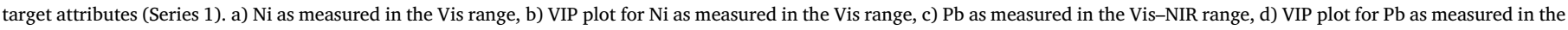
Vis-NIR range, e) Zn as measured in the MIR range and f) VIP plot for $\mathrm{Zn}$ as measured in the MIR range.

These results can be ascribed to variability in sandstone across the Adamantina Formation, where it exhibits marked cross-stratification with clay and iron oxide-rich materials (mudstone) (Soares et al., 1980). The study area is described in detail elsewhere (Camargo et al., 2014, 2015).

The highest $\mathrm{Ba}, \mathrm{Co}, \mathrm{Cu}, \mathrm{Mn}, \mathrm{Ni}$ and $\mathrm{Zn}$ contents were those found in GS III (Table 3). The lowest $\mathrm{Ba}, \mathrm{Pb}$ and $\mathrm{Zn}$ contents were below the respective quality reference value (QRV) set by CETESB (Company of Environmental Sanitary Technology of São Paulo State, Brazil) for the state of São Paulo (CETESB, 2014): 30, 17 and $60 \mathrm{mg} \mathrm{kg}^{-1}$, respectively (Table 3). QRV is a measure of the natural concentration of a given substance in non-anthropic soils (CETESB, 2001). By contrast, the highest contents in Ba (GS III) and Zn (GS I) were above the prevention value (PV): $120 \mathrm{mg} \mathrm{kg}^{-1}$ (CETESB, 2014). The prevention value sets the threshold for a potential change in the natural quality of soil (CETESB, 2001).

The Co, Cu, Mo, Ni contents along the transect were not higher than their PVs and hence of no concern (Table 3). The lowest Cr content (40 $\mathrm{mg} \mathrm{kg}^{-1}$ ) was slightly above QRV but the highest levels in GS I and II (75 mg kg ${ }^{-1}$; Table 3) exceeded PV. Manganese has no reference value because it occurs naturally in soil and also because the content in soil above which it can be hazardous to human health has not yet been established (CETESB, 2014).

\subsection{Correlation of PTEs with iron oxides and magnetic susceptibility}

Based on Pearson's correlation coefficients, clay, Fed, Feo, Hm, MS and the $\mathrm{Gb} /(\mathrm{Gb}+\mathrm{Kt})$ ratio were positively correlated with PTEs; by 
$\mathrm{Ba}$

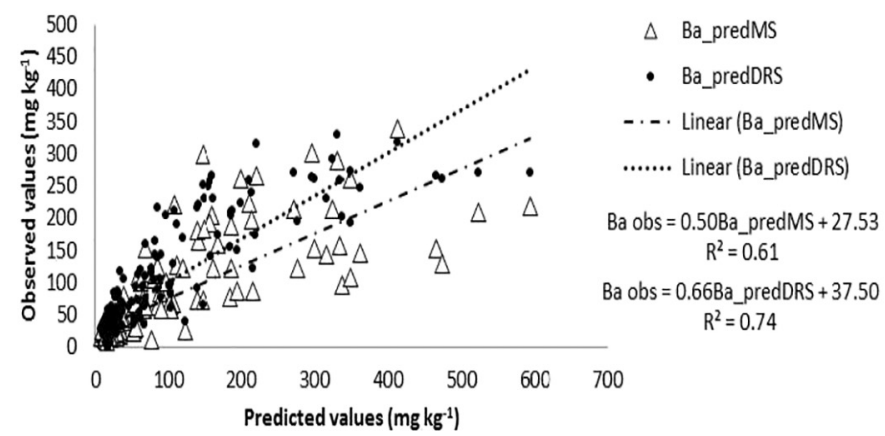

Co

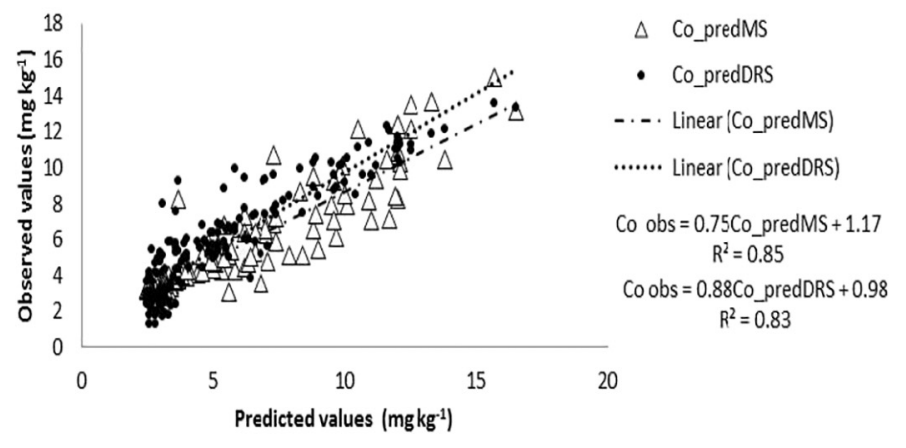

b)
$\mathrm{Cu}$

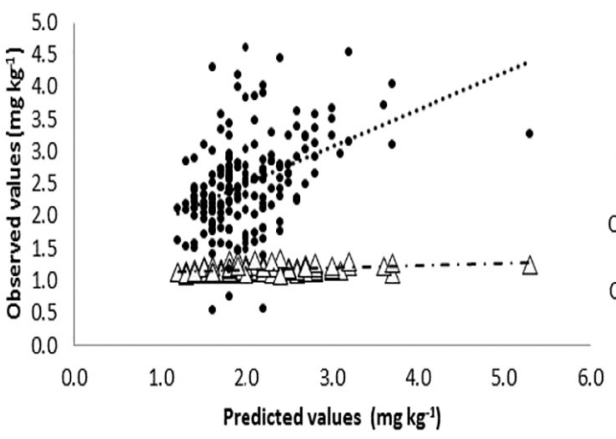

$\triangle$ Cu_predFed

- Cu_predDRS

-. - . Linear (Cu_predfed)

....... Linear (Cu_predDRS)

Cu obs $=0.04$ Cu_predFed +1.10 $R^{2}=0.15$

Cu obs $=0.57$ Co_predDRS +1.36 $R^{2}=0.18$

a)

$\mathrm{Mn}$

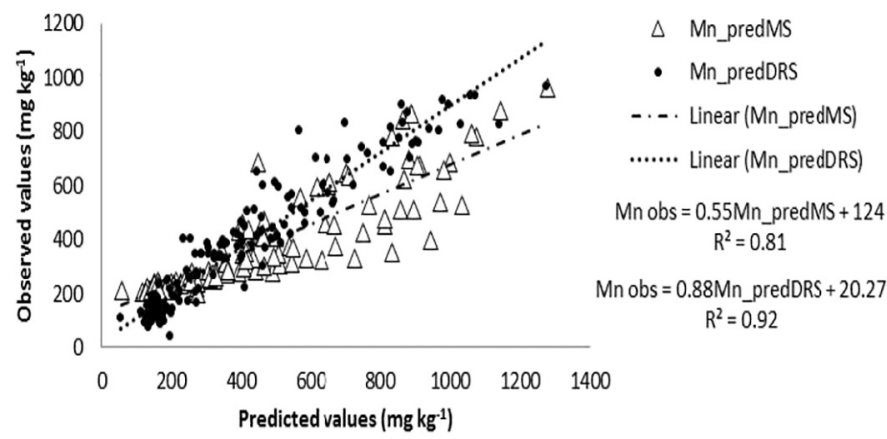

d)
$\mathrm{Ni}$

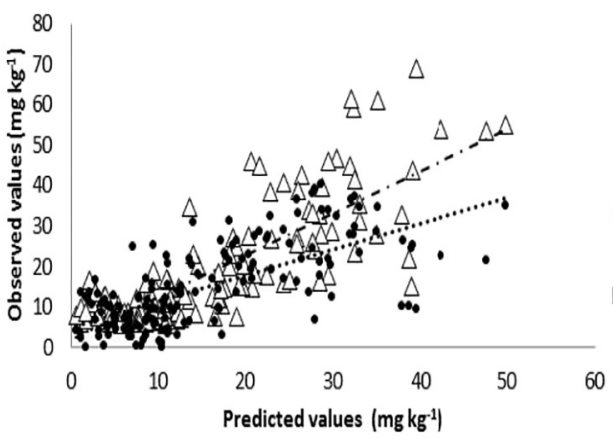

c)

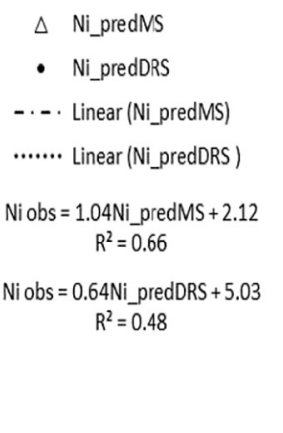

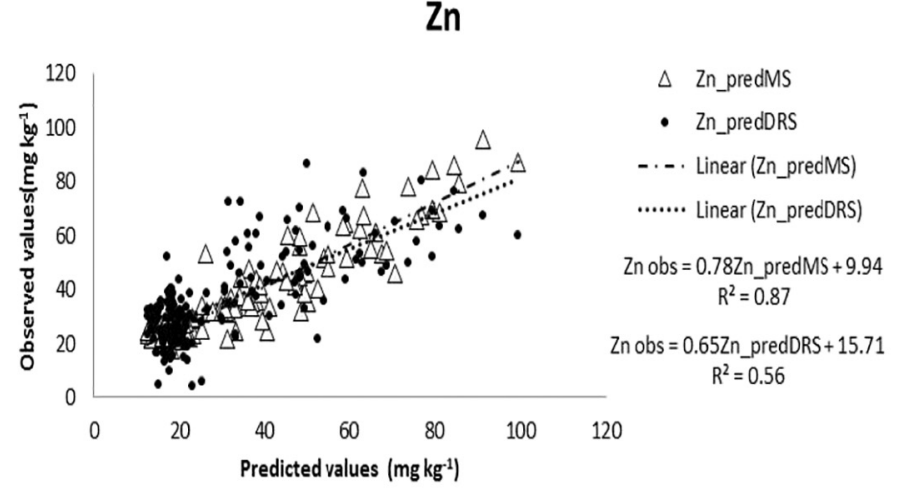

f)

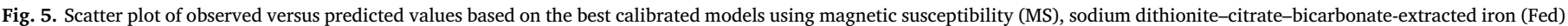
and diffuse reflectance spectroscopy (DRS) for the samples in Series 2.

exception, $\mathrm{Mo}$ and $\mathrm{Pb}$ were only correlated with the $\mathrm{Gb} /(\mathrm{Gb}+\mathrm{Kt})$ ratio (Table 4). Sand exhibited negative correlation with all elements except $\mathrm{Cr}$, Mo and $\mathrm{Pb}$. OM had low, positive correlation coefficients $(<0.34)$ with $\mathrm{Ba}, \mathrm{Cu}$ and $\mathrm{Zn}$, whereas $\mathrm{pH}$ exhibited low, negative coefficients $(<0.36)$ with $\mathrm{Ba}, \mathrm{Co}, \mathrm{Cu}$ and $\mathrm{Ni}$, but positive correlation with $\mathrm{Cr}$ (Table 4). Finally, CEC had low positive correlation coefficients with $\mathrm{Ba}, \mathrm{Cu}$ and $\mathrm{Zn}$. The positive correlations of PTE contents with clay, iron oxides and the $\mathrm{Gb} /(\mathrm{Gb}+\mathrm{Kt})$ ratio can be ascribed to the presence of the elements in the active fraction of the soil, which contains an increased number of adsorption sites.

Carbon compounds are rapidly mineralized under tropical conditions. This may have led to the low, widely variable OM contents of the soils. The little influence of $\mathrm{pH}$ and CEC on the spatial distribution of
PTEs was a result of the samples being extracted in a strongly acidic medium and hence of semi-total contents rather than available concentrations being determined. In fact, the acid digestion method used to extract PTEs failed to dissolve silicate minerals but successfully extracted adsorbed elements in iron and aluminium oxides (Ure, 1995), which may be either available to plants or leached to groundwater (Diaz-Barrientos et al., 1991).

As shown by its increased correlation coefficients relative to Feo and Gt (Table 4), hematite had a strong influence on PTE contents. All PTEs examined can be adsorbed to a variable extent by iron oxides depending on the oxide crystal shape and degree of crystallization; thus, poorly crystalline oxides with a large specific surface area can be expected to adsorb metals more readily (Yu et al., 1997). In this study, however, the 
Table 7

Fitting of model parameters to the experimental semivariograms.

\begin{tabular}{|c|c|c|c|c|c|c|c|}
\hline Attribute & Model & $C_{0}{ }^{a}$ & $C_{0}+C_{1}{ }^{\mathrm{b}}$ & $C_{0} /\left(C_{0}+C_{1}\right)^{\mathrm{c}}(\%)$ & Range (m) & $R^{2 \mathrm{~d}}$ & $\mathrm{RSS}^{\mathrm{e}}$ \\
\hline $\mathrm{Ba}_{\mathrm{obs}}$ & Gaussian & 620 & 9270 & 7 & 1021 & 0.97 & $4,122,023$ \\
\hline $\mathrm{Ba}_{\text {DRS }}$ & Gaussian & 670 & 4217 & 16 & 989 & 0.93 & $1,582,550$ \\
\hline $\mathrm{Ba}_{\mathrm{MS}}$ & Gaussian & 780 & 2918 & 27 & 1148 & 0.94 & 575,928 \\
\hline $\mathrm{Co}_{\text {obs }}$ & Spherical & 0.41 & 5.87 & 7 & 1386 & 0.93 & 3.35 \\
\hline $\mathrm{Co}_{\text {DRS }}$ & Spherical & 0.34 & 4.16 & 8 & 1166 & 0.94 & 1.33 \\
\hline $\mathrm{Co}_{\mathrm{MS}}$ & Spherical & 0.87 & 3.86 & 23 & 1290 & 0.92 & 1.10 \\
\hline $\mathrm{Cu}_{\mathrm{obs}}$ & Gaussian & 0.08 & 0.30 & 27 & 892 & 0.95 & 4.5E-03 \\
\hline $\mathrm{Cu}_{\mathrm{DRS}}$ & Gaussian & 0.15 & 0.55 & 27 & 1125 & 0.93 & $2.2 \mathrm{E}-02$ \\
\hline $\mathrm{Cu}_{\mathrm{MS}}$ & Gaussian & 0.000618 & 0.001816 & 34 & 1163 & 0.95 & $1.25 \mathrm{E}-7$ \\
\hline $\mathrm{Mn}_{\mathrm{obs}}$ & Spherical & 2000 & 33,960 & 6 & 928 & 0.95 & $6.23 E+7$ \\
\hline $\mathrm{Mn}_{\mathrm{DRS}}$ & Spherical & 1000 & 27,740 & 4 & 1051 & 0.94 & $6.12 \mathrm{E}+7$ \\
\hline $\mathrm{Mn}_{\mathrm{MS}}$ & Spherical & 2650 & 15,310 & 17 & 1392 & 0.95 & $1.05 \mathrm{E}+7$ \\
\hline $\mathrm{Ni}_{\text {obs }}$ & Spherical & 27 & 66 & 41 & 1257 & 0.92 & 200 \\
\hline $\mathrm{Ni}_{\text {DRS }}$ & Spherical & 14 & 41 & 34 & 898 & 0.90 & 103 \\
\hline $\mathrm{Ni}_{\mathrm{MS}}$ & Spherical & 27 & 117 & 23 & 1271 & 0.89 & 1408 \\
\hline $\mathrm{Zn}_{\text {obs }}$ & Spherical & 51 & 218 & 23 & 1364 & 0.95 & 2248 \\
\hline $\mathrm{Zn}_{\mathrm{DRS}}$ & Spherical & 35 & 195 & 18 & 1093 & 0.98 & 659 \\
\hline $\mathrm{Zn}_{\mathrm{MS}}$ & Spherical & 28 & 156 & 18 & 1367 & 0.95 & 1367 \\
\hline
\end{tabular}

a Nugget effect.

b Sill.

c Degree of spatial dependence (moderate with $25-75 \%$, weak with $>75 \%$, strong with $\leq 25 \%$ ).

${ }^{\mathrm{d}}$ Coefficient of determination.

e Residual sum of squares.

results may have arisen from the increased $\mathrm{Hm}$ contents relative to $\mathrm{Gt}$ and poorly crystalline iron oxides (Camargo et al., 2014). As suggested by the correlation found between iron oxides and the target elements, isomorphic substitution of $\mathrm{Fe}$ by elements such as $\mathrm{Ni}, \mathrm{Cr}, \mathrm{Co}, \mathrm{Cu}$ and $\mathrm{Zn}$ in iron oxides may be an important PTEs source in soils in addition to adsorption (Melo et al., 2001).

The correlation coefficients for MS were similar to those for $\mathrm{Hm}$ and Fed for the corresponding elements. MS is typically ascribed to ferrimagnetic iron oxides such as magnetite and maghemite. Our frequencydependent magnetic susceptibility (fdMS) values ranged from 10 to $14 \%$ (Camargo et al., 2016), which according to Dearing (1999) is suggestive of a prevalence of superparamagnetic minerals ( $>75 \%$ ). Although MS can be partly ascribed to lithogenic minerals, it was largely associated to pedogenic minerals such as maghemite and/or an intermediate ferrihydrite phase - a precursor of $\mathrm{Hm}-$ in our soils because they originated from sandstone. The intermediate ferrihydrite phase (ferrimagnetic ferrihydrite) is strongly ferrimagnetic (Michel et al., 2010) and forms by aging of its ferrihydrite precursor.

The increased specific surface area of ferrimagnetic ferrihydrite relative to $\mathrm{Hm}$ (Michel et al., 2010) resulted in an also increased number of adsorption sites for PTEs. Martínez et al. (1999) found heating synthetic ferrihydrite to decrease its specific surface area and $\mathrm{Pb}$ adsorption, and also to cause the formation of $\mathrm{Hm}$ and Gt. They had similar results with pedogenic samples. Maghemite and magnetite have also been reported to adsorb PTEs (Sidhu et al., 1980; Tuutijärvi et al., 2009).

The positive correlations between the $\mathrm{Gb} /(\mathrm{Gb}+\mathrm{Kt})$ ratio and PTE contents were due to the presence of hydroxyl functional groups on the Gb surface, which are similar to those found on iron oxides.

\subsection{Diffuse reflectance spectroscopy}

GS III exhibited lower reflectance than GS I and II in all spectral ranges (Fig. 2). Vis-NIR spectra exhibited concavities due to absorption bands typical of iron oxides (480-550 nm and $800-1000 \mathrm{~nm}$ ) and kaolinite (2200 nm) (Lindberg and Snyder, 1972; Mathews et al., 1973). The concavities in the spectra for GS III were more marked than in those for GS I and II, but the opposite held for the typical concavity of kaolinite (Fig. 2a and b). These results are consistent with the increased iron oxide contents and $\mathrm{Gb} /(\mathrm{Gb}+\mathrm{Kt})$ ratios in GS III (Tables 1 and 2).
The similarity among Vis-NIR spectra confirms that the LabSpec 5000 spectrometer is an effective choice for acquiring spectra over the wavelength range $380-2300 \mathrm{~nm}$.

The MIR spectra (Fig. 2c) also exhibited the typical concavities of gibbsite $\left(3619\right.$ and $\left.3532 \mathrm{~cm}^{-1}\right)$, kaolinite $\left(3695 \mathrm{~cm}^{-1}\right)$ and quartz $\left(1870,1790,780 \mathrm{~cm}^{-1}\right)$. The concavities for the latter two minerals were less marked in GS III than they were in GS I and II, which is consistent with the increased sand contents and $\mathrm{Gb} /(\mathrm{Gb}+\mathrm{Kt})$ ratios of GS III (Table 2).

\subsection{Multiple linear regression (MLR) and partial least-squares regression (PLSR)}

The high correlation of the soil attributes clay, MS, Hm, Fed and Feo (Table 4) with the $\mathrm{Ba}, \mathrm{Co}, \mathrm{Cu}, \mathrm{Mn}, \mathrm{Ni}$ and $\mathrm{Zn}$ contents allows the former to be used as PTEs predictors (Table 5). The $\mathrm{Gb} /(\mathrm{Gb}+\mathrm{Kt}$ ) ratio, though also correlated, was not included among the predictors owing to the high cost of its determination. Stepwise MLR calculations showed MS and Fed to be the best individual PTEs predictors; in fact, they resulted in no significant increase in $R^{2}$ when two or more attributes in combination were considered. The $R^{2}$ values for the MS-calibrated models for $\mathrm{Ba}, \mathrm{Co}, \mathrm{Mn}, \mathrm{Ni}$ and $\mathrm{Zn}$ prediction were $0.88,0.85,0.66,0.73$ and 0.55 , respectively. These are promising results since MS measurements are inexpensive, expeditious and non-destructive, so they can be used to predict PTEs contents in large numbers of samples and hence to map large areas at a detailed level. The Fed-calibrated model for $\mathrm{Cu}$ prediction -the best for this element- had $R^{2}=0.58$ (Table 5).

Table 6 show the cross-validation statistics of the models for predicting soil attributes as obtained by PLSR in the Vis, Vis-NIR and MIR range, and Figs. 3 and 4 the cross-validation plots for the best calibrated models. The best MIR-calibrated models (viz., those with the highest $R_{\text {adj }}^{2}$ and RPD values, and lowest RMSE and SDE) were those for Ba, Co, $\mathrm{Mn}$ and $\mathrm{Zn}$. RPD values exceeding 2.0 - which are deemed excellent (Chang et al., 2001) - were obtained for Ba, Co and Mn, which were thus predicted with a high accuracy. On the other hand, the RPD value for $\mathrm{Zn}, 1.3$, indicates inaccurate calibration (Chang et al., 2001). The best Vis-NIR-calibrated model was that for $\mathrm{Cu}$ (from spectra acquired with the LabSpec 5000 spectrometer), whereas the best Vis-calibrated model was that for $\mathrm{Ni}$ (from spectra obtained with the Lambda 950 spectrometer). However, the RPD value for $\mathrm{Cu}, 1.8$, suggests that this 

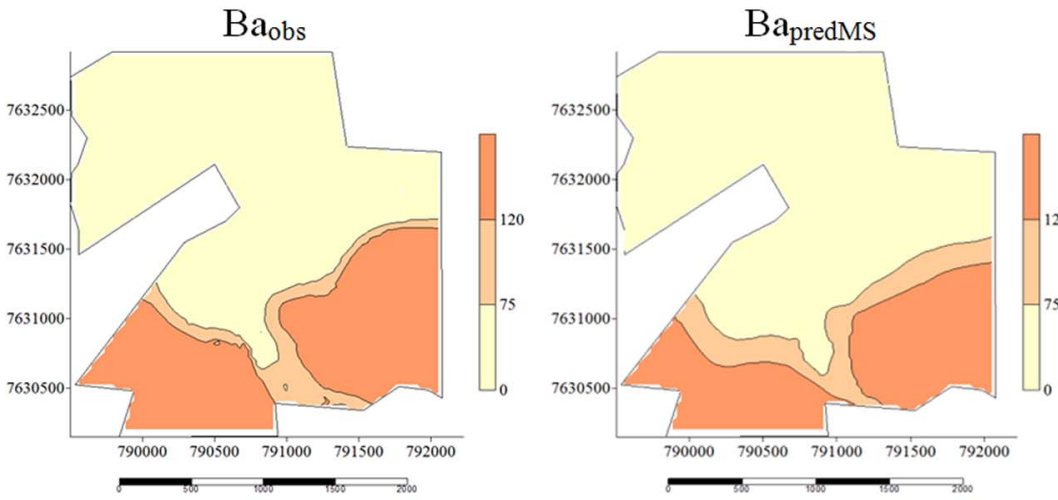

a)

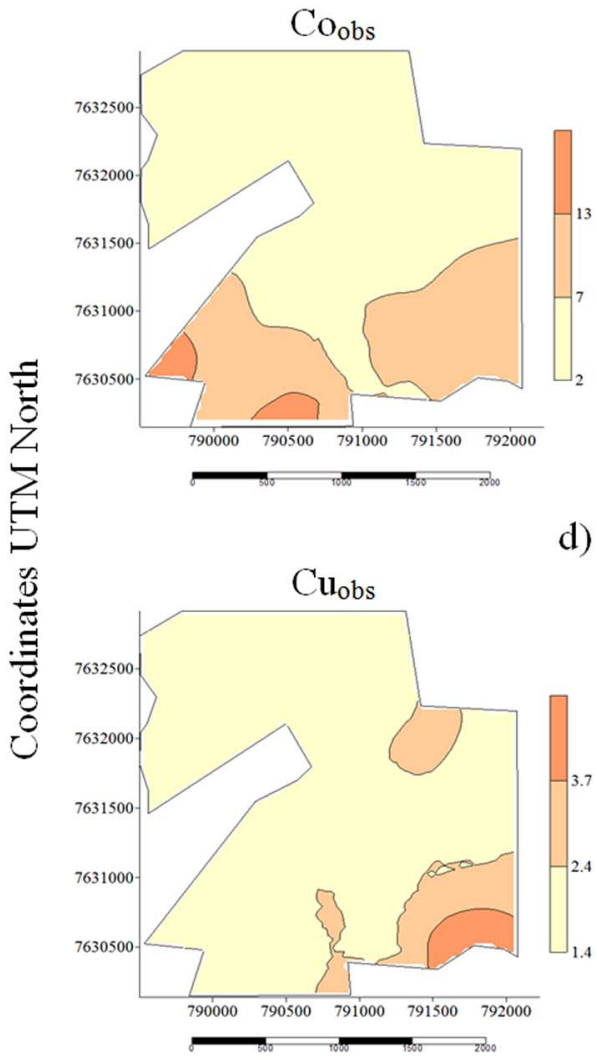

g)

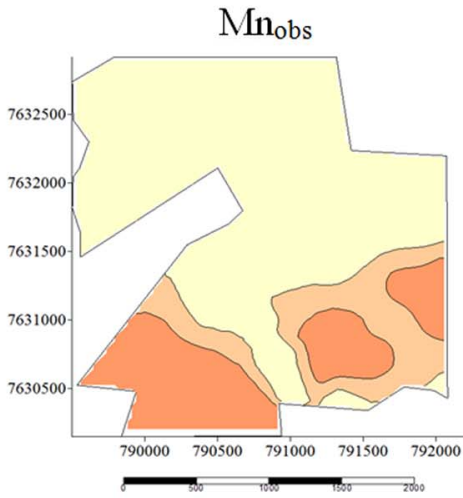

j)
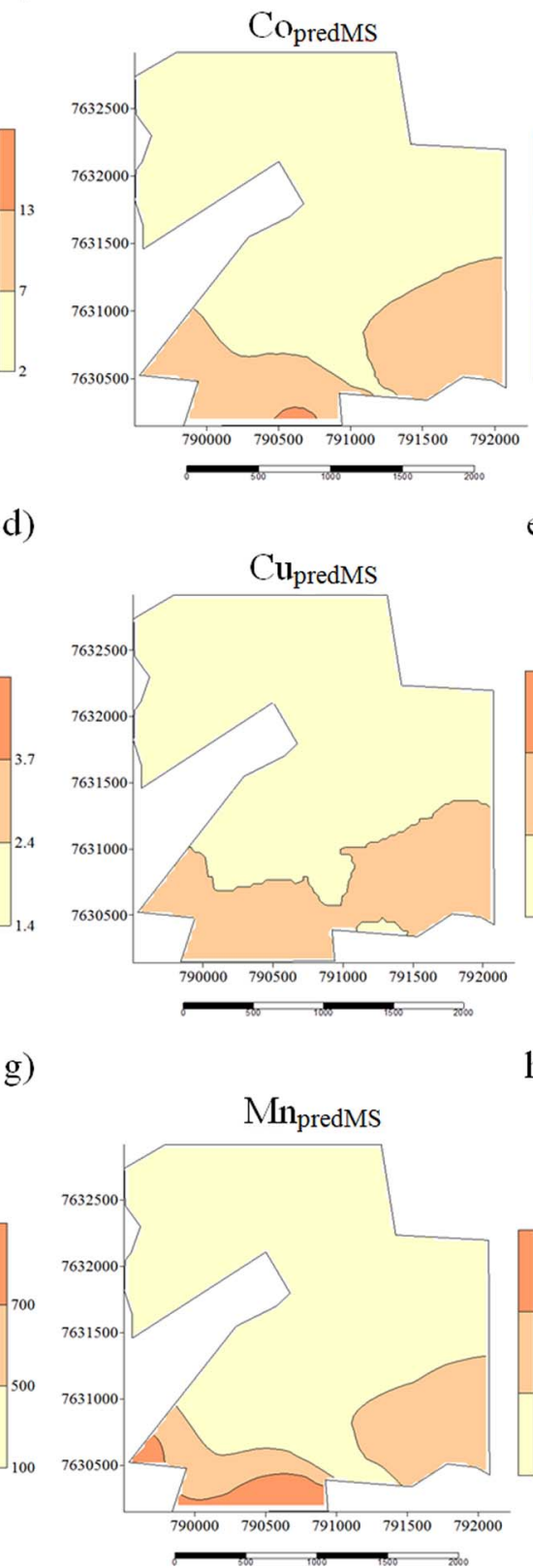

d)
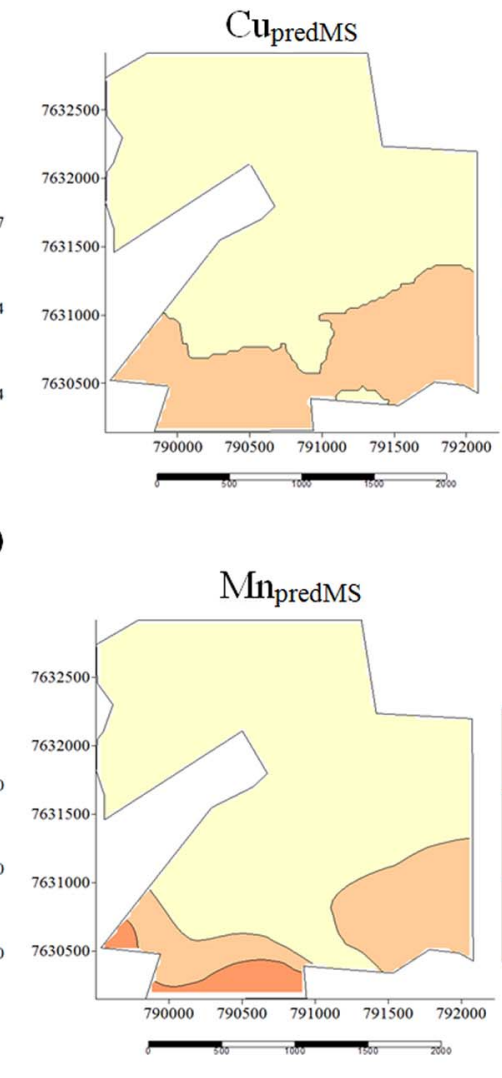

Coordinates UTM East

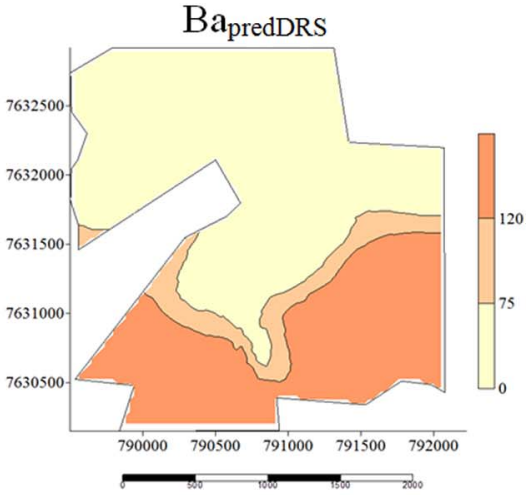

b)

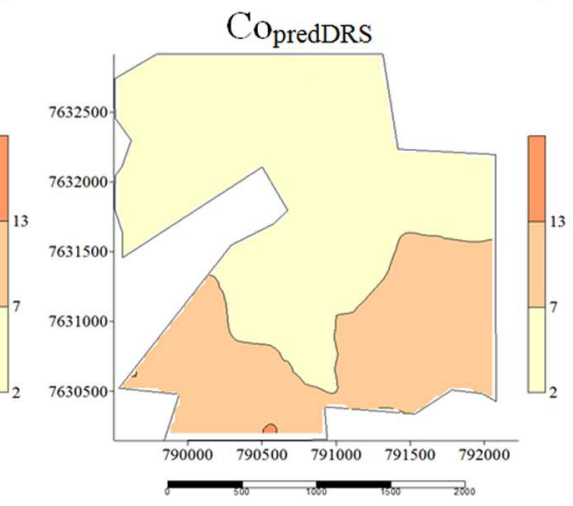

e)

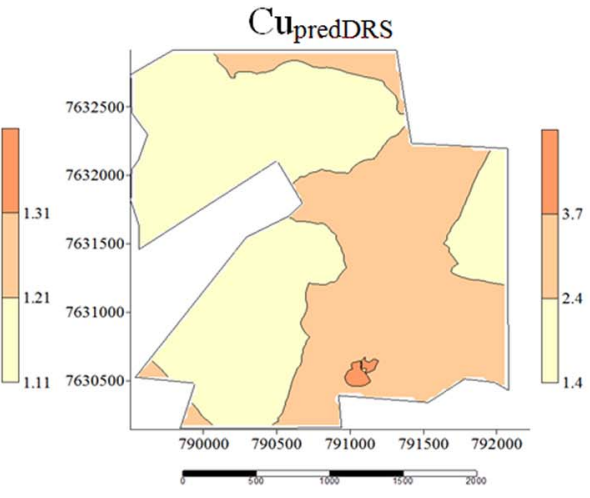

h)
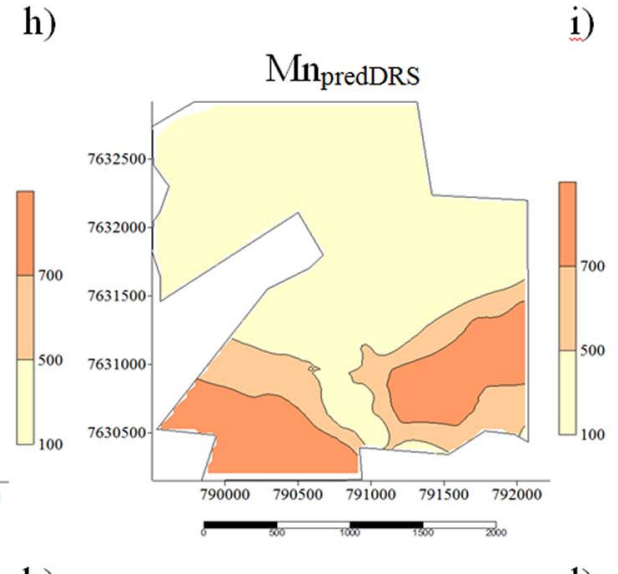

k)

i)

1)

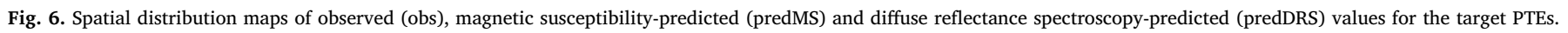




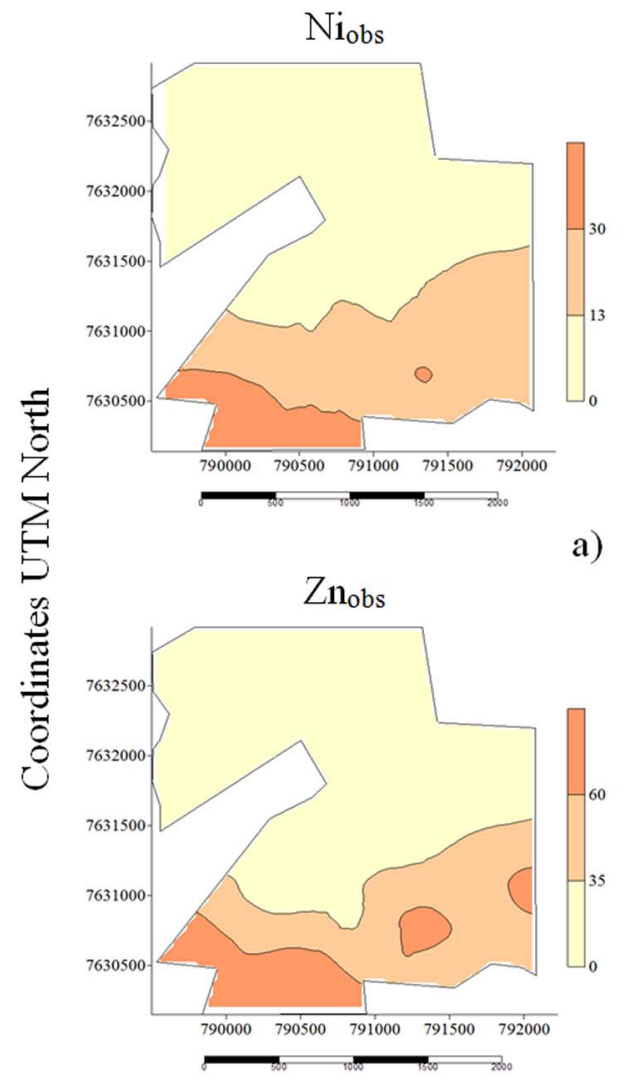

d)

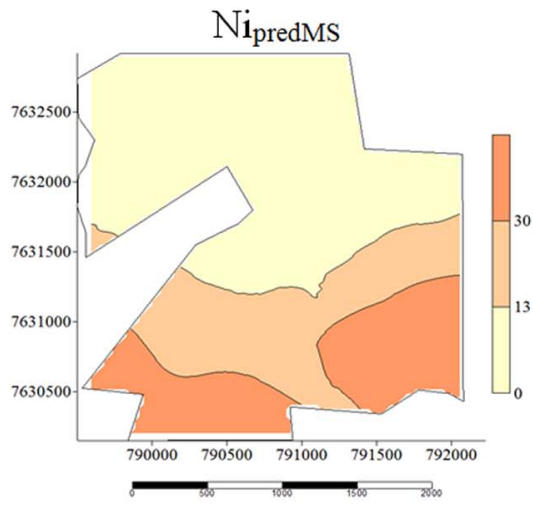

b)
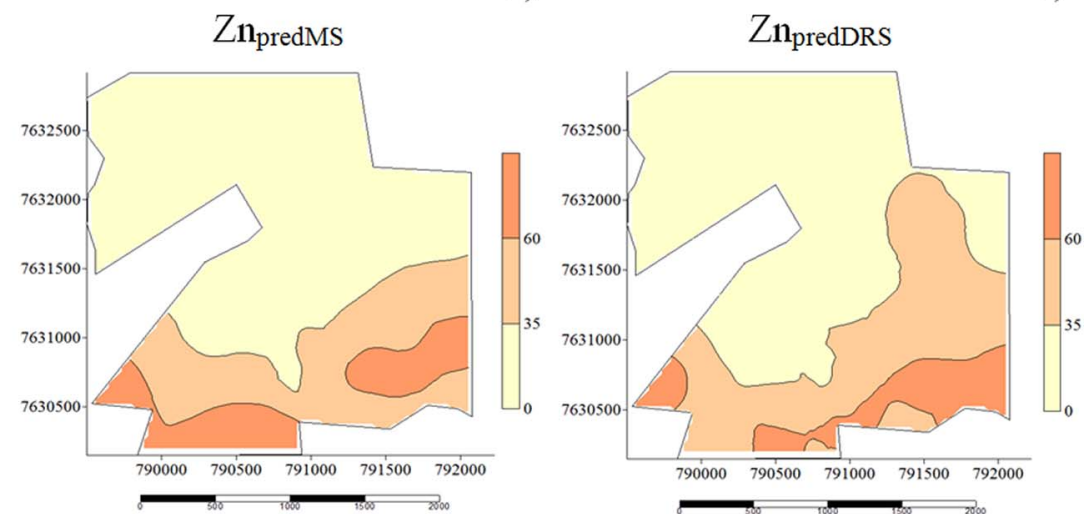

f)

e)

Coordinates UTM East

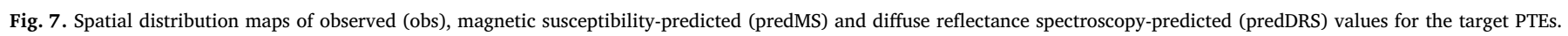

element can be more accurately predicted by using a different calibration strategy (Chang et al., 2001). Finally, the RPD value for Ni was 2.0.

Wu et al. (2007) used $61 \mathrm{~km}^{2}$ of Agrudalf soils to calibrate Vis-NIRbased prediction models; their RPD values for $\mathrm{Zn}$ and Ni were similar to ours, but those for $\mathrm{Co}$ and $\mathrm{Cu}$ were lower.

As can be seen from the VIP plots for Ba, Co and Mn in Figs. 3 and 4, the strongest peaks fell in the spectral region of $\mathrm{Kt}$ and $\mathrm{Gb}$ (viz., $2700-2900 \mathrm{~nm}$ or $3695-3532 \mathrm{~cm}^{-1}$ ), which confirms the influence of the $\mathrm{Gb} /(\mathrm{Gb}+\mathrm{Kt})$ ratio on the contents in these elements and explains why calibration in the MIR range led to better results. The strongest peaks in the VIP plots for $\mathrm{Cu}$ and $\mathrm{Ni}$ fell in the range $350-550 \mathrm{~nm}$ and can be assigned to iron oxides.

\subsection{Prediction and spatial variability of PTEs}

The MLR-calibrated prediction models based on MS (1, 4, 9, 11 and 14) and Fed (7) (Table 5), and the best PLSR-calibrated models (increased RPD values), were used to predict the $\mathrm{Ba}, \mathrm{Co}, \mathrm{Cu}, \mathrm{Mn}, \mathrm{Ni}$ and $\mathrm{Zn}$ contents for the data points of Series 2 (Fig. 5). The best predictions for $\mathrm{Co}, \mathrm{Ni}$ and $\mathrm{Zn}$ were obtained with the MS-based models $\left(R^{2}\right.$ was 0.85 , 0.66 , and 0.87 , respectively). On the other hand, the best predictions for $\mathrm{Ba}, \mathrm{Cu}$ and $\mathrm{Mn}$ were those provided by the DRS-based models $\left(R^{2}\right.$ was $0.73,0.18$ and 0.91 , respectively) (Fig. 5). The predicted and observed PTE contents were subjected to geostatistical analysis (Table 7). All PTEs values, whether predicted or experimental, exhibited spatial dependence.

The maps constructed by using ordinary kriging showed the spatial distribution pattern for the observed PTE values at the study site (Figs. 6 and 7) to be similar to those for the maps based on iron oxides and MS. Camargo et al. (2015, 2016) previously found the greatest, iron oxide and MS values in GS III. These authors found more marked spatial variation of iron oxides and MS in this geomorphic surface, which was also the case with PTEs (largest number of content classes) in this work. The fact that GS III is an unstable area may thus have led to greater variations in the target attributes; thus, according to Daniels et al. (1970) and Lepsch et al. (1977), soils developing on newer surfaces exhibit more marked differences in their attributes. The QRV and PV values for Ba, Ni and Zn exceeded the limit in GS III, but the QRV values fell under the limit in GS I. As shown by these results, properly understanding the presence of PTEs at a local scale requires considering spatial variability in iron oxides.

The spatial distribution maps for MLR- and PLSR-predicted values were similar to those for the observed $\mathrm{Ba}$, Co, and $\mathrm{Zn}$ contents. The maps for Mn MRL-predicted values exhibited overestimated areas in GS III, and so did the MLR- and PLSR-predicted maps for Ni. The differences arose from error propagation during ordinary kriging calibration, prediction and interpolation (Burrough \& McDonnell, 1998). This outcome is consistent with the visual difference between maps based on observed and predicted values. However, it should be emphasized that soil mapping is rarely error-free (Brown and Heuvelink, 2005; Nol et al., 2010); also, overestimated values from calibrated models fall in the same region as the greatest observed values. Therefore, though less accurate, the calibrated models for Mn and Ni are still useful to identify areas with potential problems.

Spectroscopy has recently been used for PTE prediction and using iron oxides confirms its effectiveness for mapping the elements from the same MS-based predictions as the PTEs. Although the calibrated models based on Vis-NIR data had smaller RPD values than those based on MIR data, they were still acceptable for most of the target PTEs. Thus, 
inexpensive portable equipment can provide acceptable predictions and may further facilitate the acquisition of samples with a view to mapping large areas at a detailed level.

The sampling scheme used here was effective in capturing spatial variability in iron oxides (Camargo et al., 2014, 2015) and hence in PTEs. Understanding the influence of geomorphic surfaces on spatial variability in iron oxides and PTEs may be useful to resample the elements concerned in follow-up studies (e.g., after remedial measures have been applied). In this specific case, an increased number of samples would be needed at locations of increased spatial variability.

The PTE prediction methods used in this study have a low cost/ benefit ratio and may be useful to gather information for pollution risk assessment and remediation. The predictors and calibration strategies used may require adaptation in areas with mineralogically different soils and/or other types of landscape.

\section{Conclusions}

The mapping of areas can be improved by using magnetic susceptibility and diffuse reflectance spectroscopy to predict PTEs contents. The prediction models for $\mathrm{Ba}, \mathrm{Co}, \mathrm{Mn}, \mathrm{Ni}$, and $\mathrm{Zn}$ were acceptably calibrated from magnetic susceptibility (MS) and diffuse reflectance spectroscopy (DRS) measurements. Contents in Ba and Mn were better predicted by DRS-calibrated models, and those in Co, Ni and Zn by MScalibrated models. The correlation between PTE and free iron contents, as well as their spatial pattern, confirms the usefulness of these alternative methods for predicting the contents in potentially toxic elements of soil.

\section{Acknowledgements}

LAC is grateful to the FAPESP (São Paulo Research Foundation Proc. FAPESP 2012/20681-0) and to the Servicio Central de Ayuda a la Investigación (SCAI) of the Universidad de Córdoba, where the measurements were carried out of MIR. JMJ, GTP and LRFA are grateful to the CNPq (National Council for Scientific and Technological Development) for the granting of research scholarships.

\section{References}

Alloway, B.J., 1995. Heavy Metals in Soils, 2nd ed. Blackie Academic and Professional, London.

Brown, J.D., Heuvelink, G.B.M., 2005. Assessing uncertainty propagation through physically based models of soil water flow and solute transport. In: Anderson, M.G. (Ed.), Encyclopedia of Hydrologic Sciences. Wiley, Chichester, pp. 1181-1195.

Burak, D.L., Fontes, M.P.F., Santos, N.T., Monteiro, L.V.S., Martins, E.S., Becquer, T., 2010. Geochemistry and spatial distribution of heavy metals in Oxisols in a mineralized region of the Brazilian Central Plateau. Geoderma 160, 131-142.

Burrough, P.A., McDonnell, R., 1998. Error propagation in numerical modelling. In: Burrough, P.A., McDonnell, R. (Eds.), Principles of Geographical Information Systems. Oxford University Press, New York, pp. 241-264.

Camargo, L.A., Marques Júnior, J., Pereira, G.T., Bahia, A.S.R.S., 2014. Clay mineralogy and magnetic susceptibility of Oxisols in geomorphic surfaces. Sci. Agric. 71, 244-256.

Camargo, L.A., Marques, J.R., Barrón, V., Alleoni, L.R.F., Barbosa, R.S., Pereira, G.T., 2015. Mapping of clay, iron oxide and adsorbed phosphate in Oxisols using diffuse reflectance spectroscopy. Geoderma 251-252, 124-132.

Camargo, L.A., Marques, J.R., Pereira, G.T., Alleoni, L.R.F., Bahia, A.S.R.S., Teixeira, D.D.B., 2016. Pedotransfer functions to assess adsorbed phosphate using iron oxide content and magnetic susceptibility in an Oxisol. Soil Use Manag. 32, 172-182.

Cattle, J.A., McBratney, A.B., Minasny, B., 2002. Kriging method evaluation for assessing the spatial distribution of urban soil lead contamination. J. Environ. Qual. 31, 1576-1588.

CETESB, 2001. Relatório de estabelecimento de Valores Orientadores para Solos e Águas Subterrâneas no Estado de São Paulo - CETESB.

CETESB, 2014. Decisão de diretoria N 045/2014/ - Aprovação dos Valores Orientadores para Solos e Águas Subterrâneas no Estado de São Paulo. CETESB, São Paulo.

Chang, C.W., Laird, D.A., Mausbach, M.J., Hurburgh, C.R., 2001. Near-infrared reflectance spectroscopy-principal components regression analyses of soil properties. Soil Sci. Soc. Am. J. 65, 480-490.

Colombo, C., Palumbo, G., Iorio, E.D., Sellitto, V.M., Comolli, R., Stellacci, A.M., Castrignanò, A., 2014. Soil organic carbon variation in alpine landscape (Northern Italy) as evaluated by diffuse reflectance spectroscopy. Soil Sci. Soc. Am. J. 78,
794-804.

Daniels, R.B., Gamble, E.E., Cady, J.G., 1970. Some relations among coastal plain soils and geomorphic surfaces in North-Carolina. Soil Sci. Soc. Am. Proc. 34, 648-653.

Day, P.R., 1965. Particle fraction and particle fractionation and particle-size analysis. In: Black, C.A. (Ed.), Methods of Soil Analysis. American Society of Agronomy, Madison, pp. 545-566.

Dearing, J., 1999. Environmental Magnetic Susceptibility. Using the Bartington MS2 System. pp. 55.

Diaz-Barrientos, E., Madrid, L., Cabrera, F., Contreras, M.C., 1991. Comparison of two methods of sample preparation for determination by atomic absorption spectrophotometry of heavy metals in soils and sediments. Commun. Soil Sci. Plant Anal. 22, 1559-1568.

Geladi, P., Kowalski, B.R., 1986. Partial least-squares regression: a tutorial. Anal. Chim. Acta $185,1-17$.

Guerrero, C., Wetterlind, J., Stenberg, B., Mouazen, A.M., Gabarrón-Galeote, M.A., Ruiz Sinoga, J.D., Zornoza, R., Viscarra Rossel, R.A., 2016. Do we really need large spectral libraries for local scale SOC assessment with NIR spectroscopy? Soil Tillage Res. 155, 501-509.

Horta, A., Malone, B., Stockmann, U., Minasny, B., Bishop, T.F.A., McBratney, A.B., Pallasser, R., Pozza, L., 2015. Potential of integrated field spectroscopy and spatial analysis for enhanced assessment of soil contamination: a prospective review. Geoderma 241-242, 180-209.

Jackson, M.L., 1985. Soil Chemical Analysis, 2nd ed. (930p, Madison).

Lagacherie, P., McBratney, A.B., 2007. Spatial soil information systems and spatial soil inference systems: perspectives for digital soil mapping. In: Lagacherie, P., McBratney, A.B., Voltz, M. (Eds.), Digital Soil Mapping: An Introductory Perspective. Elsevier, Amsterdam, pp. 3-24.

Lepsch, I.F., Buol, S.W., Daniels, R.B., 1977. Soil-landscape relationships in an area of the Occidental Plateau of São Paulo, Brazil: I. Geomorphic Madison surface and soil mapping units. Soil Sci. Soc. Am. J. 41, 104-109.

Lin, C., Zhou, S.L., Wu, S.H., Zhu, Q., Dang, Q., 2014. Spectral response of different eroded soils of subtropical in China: a case study in Changting County, China. J. Mt. Sci. 11, 697-707.

Lindberg, J.D., Snyder, D.G., 1972. Diffuse reflectance spectra of several clay minerals. Am. Mineral. 57, 485-493.

Martínez, C.E., Sauvé, S., Jacobson, A., McBrade, M.B., 1999. Thermally induced release of adsorbed $\mathrm{Pb}$ upon aging ferrihydrite and soil oxides. Environ. Sci. Technol. 33, 2016-2020.

Mathews, H.L., Conningham, R.L., Petersen, G.W., 1973. Spectral reflectance of selected Pennsylvania soils. Soil Sci. Soc. Am. Proc. 37, 421-424.

McKeague, J.A., Day, J.H., 1966. Dithionite and oxalate extractable $\mathrm{Fe}$ and $\mathrm{Al}$ as aids in differentiating various classes of soils. Can. J. Soil Sci. 46, 13-32.

Mehra, O.D., Jackson, M.L., 1960. Iron oxide removal from soils and clays by a dithionite- citrate system buffered with sodium bicarbonate. Clay Clay Miner. 5, 317-327.

Melo, V.F., Fontes, M.P.F., Novais, R.F., Singh, B., Schaefer, C.E.G.R., 2001 Características dos óxidos de ferro e de alumínio de diferentes classes de solos. Rev. Bras. Ciênc. Solo 25, 19-32.

Michel, F.M., Barrón, V., Torrent, J., Morales, M.P., Serna, C.J., Boily, J.F., Liu, Q., Ambrosini, A., Cismasu, A.C., Brown, G.E., 2010. Ordered ferrimagnetic form of ferrihydrite reveals links among structure, composition, and magnetism. Proc. Natl. Acad. Sci. 107, 2787-2792.

Morton-Bermea, O., Hernandez, E., Martinez-Pichardo, E., Soler-Arechalde, A.M., Lozano Santa-Cruz, R., Gonzalez-Hernandez, G., Beramendi-Orosco, L., Urrutia-Fucugauchi, J., 2009. Mexico City topsoils: heavy metals vs. magnetic susceptibility. Geoderma $151,121-125$.

Nanos, N., Martín, J.A.R., 2012. Multiscale analysis of heavy metal contents in soils: spatial variability in the Duero river basin (Spain). Geoderma 189-190, 554-562.

Nol, L., Heuvelink, G.B.M., Veldkamp, A., de Vries, W., Kros, J., 2010. Uncertainty propagation analysis of an $\mathrm{N}_{2} \mathrm{O}$ emission model at the plot and landscape scale. Geoderma 159, 9-23.

Norrish, K., Taylor, R.M., 1961. The isomorphous replacement of iron by aluminium in soil goethites. J. Soil Sci. 12, 294-306.

Oliver, M.A., Webster, A.R., 2014. A tutorial guide to geostatistics: computing and modelling variograms and kriging. Catena 113, 56-69.

Raij, B., van Quaggio, J.A., Cantarella, H., Ferreira, M.E., Lopes, A.S., Bataglia, O.C., 1987. Análise química do solo para fins de fertilidade. Fundação Cargill, Campinas.

Raij, B., van Andrade, J.C., Cantarella, H., Quaggio, J.A., 2001. Análise química para avaliação da fertilidade de solos tropicais. Instituto Agronômico, Campinas.

Shi, T., Chen, Y., Liu, Y., Wu, G., 2014. Visible and near-infrared reflectance spectroscopy - an alternative for monitoring soil contamination by heavy metals. J. Hazard. Mater. 265, 166-176.

Sidhu, P.S., Gilkes, R.J., Posner, A.M., 1980. The behavior of Co, Ni, Zn, Cu, Mn, and Cr in magnetite during alteration to maghemite and hematite. Soil Sci. Soc. Am. J. 44, $135-138$.

Soares, P.C., Landim, P.M.B., Fúlfaro, V.J., Sobreiro Neto, A.F., 1980. Ensaio de caracterização estratigráfica do Cretáceo no Estado de São Paulo: Grupo Bauru. Rev. Bras. Geogr. 10, 177-185.

Soil Survey Staff, 2010. Keys to Soil Taxonomy, 11th ed. USDA-Natural Resources Conservation Service, Washington.

Stenberg, B., Viscarra-Rossel, R.A., Mouazen, A.M., Wetterlind, J., 2010. Visible and near infrared spectroscopy in soil science. In: Sparks, D.L. (Ed.), Advances in Agronomy. Vol. 107. Academic Press, Burlington, pp. 163-215.

Tuutijärvi, T., Lu, J., Sillanpää, M., Chen, G., 2009. As(V) adsorption on maghemite nanoparticles. J. Hazard. Mater. 166, 1415-1420.

United States Environmental Protection Agency - USEPA Method 3051A - 1996 Microwave assisted acid digestion of sediments, sludges, soils, and soils. http://www. 
epa.gov/storet/archive/modern/doc/FieldLabAnltPrcdAndEqpDetail.pdf > (accessed: 20.08.2012).

Ure, A.M., 1995. Methods of analysis for heavy metals in soil. In: Alloway, B.J. (Ed.), Heavy Metals in Soils. Blackie Academic and Professional, London, pp. 58-102. Vieira, S.R., 2000. Geoestatística em estudos de variabilidade espacial do solo. In: Novais, R.F., Alvarez, V.H., Schaefer, G.R. (Eds.), Tópicos em ciência do solo. Sociedade Brasileira de Ciência do Solo, Viçosa. Vol. 1. pp. 1-54.

Viscarra Rossel, R.A., Behrens, T., Ben-Dor, E., Brown, D.J., Demattê, J.A.M., Shepherd, K.D., Shi, Z., Stenberg, B., Stevens, A., Adamchuk, V., Aïchi, H., Barthès, B.G., Bartholomeus, H.M., Bayer, A.D., Bernoux, M., Böttcher, K., Brodský, L., Du, C.W., Chappell, A., Fouad, Y., Genott, V., Gomez, C., Grunwald, S., Gubler, A., Guerrero, C., Hedley, C.B., Knadel, M., Morrás, H.J.M., Nocita, M., Ramirez-Lopez, L., Roudier, P., Campos, Rufasto, Sanborn, E.M., Sellitto, P., Sudduth, V.M., Rawlins, K.A., Walter, B.G., Winowiecki, C., Hong, L.A., Ji, S.Y., W, 2016. A global spectral library to characterize the world's soil. Earth Sci. Rev. 115, 198-230.
Viscarra-Rossel, R.A., 2008. ParLeS: software for chemometric analysis of spectroscopic data. Chemom. Intell. Lab. Syst. 90, 72-83.

Viscarra-Rossel, R.A., Bui, E.N., de Caritat, P., McKenzie, N.J., 2010. Mapping iron oxides and color of Australia soil using visible-near-infrared reflectance spectra. J. Geophys. Res. 115 (F04031).

Wold, S., Sjöström, M., Eriksson, L., 2001. PLS-regression: a basic tool of chemometrics. Chemom. Intell. Lab. Syst. 58, 109-130.

Wu, Y., Chen, J., Junfeng, J., Gong, P., Liao, Q., Tian, Q., Ma, H.A., 2007. Mechanism study of reflectance spectroscopy for investigating heavy metals in soils. Soil Sci. Soc. Am. J. 71, 918-926.

Yan, B., Fang, N.F., Zhang, P.C., Shi, Z.H., 2013. Impacts of land use change on watershed streamflow and sediment yield: an assessment using hydrologic modelling and partial least squares regression. J. Hydrol. 484, 26-37.

Yu, T.R., Sun, H.Y., Zhang, H., 1997. Specific adsorption of cations. In: Yu, T.R. (Ed.), Chemistry of Variable Charge Soils. Oxford University Press, New York, pp. 140-174. 